NBER WORKING PAPER SERIES

\title{
FLIGHT-TO-QUALITY OR FLIGHT-TO-LIQUIDITY? EVIDENCE FROM THE EURO-AREA BOND MARKET
}

\author{
Alessandro Beber \\ Michael W. Brandt \\ Kenneth A. Kavajecz \\ Working Paper 12376 \\ http://www.nber.org/papers/w12376
NATIONAL BUREAU OF ECONOMIC RESEARCH
1050 Massachusetts Avenue
Cambridge, MA 02138
July 2006

Beber is at HEC, University of Lausanne, Brandt is at the Fuqua School of Business, Duke University and is also affiliated with the NBER, and Kavajecz is at the School of Business, University of Wisconsin Madison. We gratefully acknowledge the helpful comments from seminar participants at Notre Dame University, University of North Carolina, and the University of Wisconsin. We have also benefitted greatly from the comments of Shane Corwin, Joel Hasbrouck, Paul Schultz and Richard Sheehan. All remaining errors are our own. Address correspondence to Kenneth Kavajecz, School of Business, University of Wisconsin - Madison, 975 University Avenue, Madison, Wisconsin 53706. Phone: (608) 265-3494 or kkavajecz@bus.wisc.edu. The views expressed herein are those of the author(s) and do not necessarily reflect the views of the National Bureau of Economic Research.

(C2006 by Alessandro Beber, Michael W. Brandt and Kenneth A. Kavajecz. All rights reserved. Short sections of text, not to exceed two paragraphs, may be quoted without explicit permission provided that full credit, including $@$ notice, is given to the source. 
Flight-to-Quality or Flight-to-Liquidity? Evidence From the Euro-Area Bond Market

Alessandro Beber, Michael W. Brandt and Kenneth A. Kavajecz

NBER Working Paper No. 12376

July 2006

JEL No. G0, G12

\begin{abstract}
$\underline{\text { ABSTRACT }}$
Do bond investors demand credit quality or liquidity? The answer is both, but at different times and for different reasons. Using data on the Euro-area government bond market, which features a unique negative correlation between credit quality and liquidity across countries, we show that the bulk of sovereign yield spreads is explained by differences in credit quality, though liquidity plays a non-trivial role especially for low credit risk countries and during times of heightened market uncertainty. In contrast, the destination of large flows into the bond market is determined almost exclusively by liquidity. We conclude that credit quality matters for bond valuation but that, in times of market stress, investors chase liquidity, not credit quality.
\end{abstract}

Michael W. Brandt

Fuqua School of Business

Duke University

Box 90120

One Towerview Drive

Durham, NC 27708

mbrandt@duke.edu 


\section{Introduction}

In times of economic distress, we often observe investors rebalance their portfolios toward less risky and more liquid securities, especially in fixed income markets. This phenomenon is commonly referred to as a flight-to-quality and a flight-to-liquidity, respectively. While the economic motives of these two phenomena are clearly distinct from each other, empirically disentangling a flight-to-quality from a flight-to-liquidity is difficult because, as Ericsson and Renault (2006) show in the context of the U.S. corporate bond market, these two attributes of a fixed income security (credit quality and liquidity) are usually positively correlated. For example, U.S. Treasuries have less credit risk and are more liquid than corporate bonds. When we observe investors reduce their corporate bond holdings and increase their Treasury holdings it is therefore unclear whether they do so because of credit or liquidity concerns.

The goal of our paper is to determine empirically the extent to which investors are concerned about credit quality and liquidity unconditionally, as well as conditional on times of heightened market uncertainty or rebalancing activity. We accomplish this by studying yield spreads and orderflow in the Euro-area government bond market which exhibits a strong and unique negative relation between credit quality and liquidity, as opposed to the strong positive association found in U.S. debt markets. To appreciate this difference, consider that the credit quality of sovereign debt increases with a country's fiscal discipline (i.e., lower deficit/debt to GDP ratio). At the same time the liquidity of sovereign bonds depends on the quantity of outstanding debt which, holding the size of the economy constant, decreases with a country's fiscal discipline. Italy's sovereign debt, for example, is among the most liquid but also most risky in the Euro-area government bond market. This negative association between credit quality and liquidity is the key aspect of our data that allows us to empirically disentangle flights-toquality and flights-to-liquidity.

More specifically, we study the yield spreads (relative to a common Euro-LIBOR yield curve) and orderflow for 10 Euro-area countries with active sovereign debt markets. We use the MTS interdealer fixed income securities data, a relatively new dataset containing Euro-area government security wholesale transactions and limit order books. ${ }^{1}$ These data have two advantages. First, all the fixed income securities therein are based on the actions of the same

\footnotetext{
${ }^{1}$ The MTS data are essentially the European equivalent of the U.S. GovPX data.
} 
European Central Bank, thereby isolating the credit quality and liquidity differences across countries. Second, as will become apparent later, we can construct precise measures of liquidity for these data, in contrast to what is generally possible to obtain for fixed income securities. In addition to the MTS data, we utilize data from the sovereign credit default swap (CDS) market to obtain an exogenous estimate of credit quality for each of the countries in the sample.

Our main empirical finding is that investors care about both credit quality and liquidity, but they do so at different times and for different reasons. We document that the bulk of sovereign yield spreads is explained by differences in credit quality, though liquidity plays a non-trivial role especially for low credit risk countries and during times of heightened market uncertainty. When we investigate flights directly, we find that the destination of large flows into (as well as out of) the bond market is determined almost exclusively by liquidity. Furthermore, when we condition on periods of large flows into or out of the bond market, liquidity explains a substantially greater proportion of sovereign yield spreads, consistent with a heightened impact of order flow on bond prices. We conclude from this evidence that, while credit quality matters for bond valuation, in times of market stress, investors chase liquidity, not credit quality. ${ }^{2}$

The question of whether investors are more concerned with credit quality or liquidity is crucial for academics, practitioners, and policy makers alike. For academics, our results point to specific avenues that are likely to be fruitful in improving our current term structure models by providing a better understanding of cross-market dynamics and the sources of risk premia. For practitioners, understanding the implications of credit quality and liquidity on fixed income securities aid in both firm-level issuance decisions as well as trading strategies of fixed income portfolio managers. Finally, our work is important to policy makers, whose objective is the viability of the markets, because it suggests ways to mitigate 'peak-load' problems induced by flights into and out of financial markets as was seen during the Russian debt crisis in 1998.

Section 2 discusses the related literature. Section 3 describes our data and methodology. Section 4 reports our empirical results and Section 5 concludes.

\footnotetext{
${ }^{2}$ It is important to note that our analysis of flights is specific to the choice of securities within a single asset class Euro area government bonds, and does not necessarily apply to movements across asset classes. We restrict our analysis to the government bond market because we cannot empirically characterize with the same level of detail the rebalancing activities across asset classes.
} 


\section{Related literature}

Our study is related to three separate segments of the finance literature. First, our analysis is related to research studying the set of sovereign debt markets operating within the European Monetary Union. This collection of work has focused primarily on the determinants of yield changes or of yield spreads within and across European Union countries. Geyer, Kossmeier, and Pichler (2004) and Menkveld, Cheung, and de Jong (2005) employ factor models in their analysis while Codogno, Favero and Missale (2003) and Favero, Pagano and Von Thadden (2005) relate yield spreads to movements in U.S. debt markets. Other research involving the European Union bond markets focuses on the properties of orderflow and trading costs (Cheung, de Jong, and Rindi, 2003) or on determining which fixed income securities act as the benchmark for a given maturity (Dunne, Moore, and Portes, 2003). While our analysis is related to the above research by virtue of studying a common set of European Union fixed income markets, our analysis focuses instead on the extent to which credit and liquidity concerns jointly determine yields and net orderflow (flights) in European bond markets.

Our analysis is also naturally related to the literature on credit risk. Early work by CollinDufresne, Goldstein, and Martin (2001) found that changes in yield spreads were not associated with natural credit risk factors or standard proxies for liquidity. In contrast, more recent work by Duffie, Pedersen, and Singleton (2003) and Longstaff, Mithal, and Neis (2005) argue that both credit and liquidity concerns are critical components of yield spreads. Specifically, Longstaff, Mithal, and Neis (2005) use, like us, information from credit default swaps to obtain direct measures of the size of default and non-default components in corporate spreads. While they find the majority of the yield spread is due to default risk, the non-default spread component is substantial, time-varying and related to bond-specific and macroeconomic illiquidity.

Finally our work is also related to the burgeoning literature on the importance of liquidity. While there is little debate that the liquidity of a security affects its price, see for example, Amihud and Mendelson (1986) and Chordia, Roll and Subrahmanyam (2000), the debate has shifted toward determining whether the level of liquidity, the change in liquidity (liquidity risk), or both, have an impact on security prices. Goldreich, Hanke and Nath (2004) and Longstaff (2004) provide evidence that the level of liquidity is priced through the comparison of carefully chosen samples of on and off-the-run paired Treasury securities and 
Treasury and RefCorp securities respectively. Pastor and Stambaugh (2003) argue instead that liquidity risk, the possibility that securities will become illiquid precisely when traders want to exit their positions, is the important factor priced in asset returns. In addition to this empirical work, there are three closely related theoretical models which provide some guidance to the role of liquidity in our empirical study: Vayanos (2004), Acharya and Pedersen (2005) and Ericsson and Renault (2006). The empirical implications of these models are: (1) preference for liquidity is time-varying and increasing with volatility, (2) the correlation between similar assets increases with liquidity, and (3) illiquid assets are more sensitive to the common liquidity factor.

The critical difference between the papers on credit quality and liquidity cited above and our work is their exclusive focus on pricing/spreads versus our joint focus on pricing and trading activity/orderflow. We show that different attributes of securities have a differing importance for investors when they price them unconditionally and when they price them during times of high liquidity demands (flights). This analysis speaks more generally to the question of which attributes of securities are priced conditional on market stress and is thus closer to the perspective of pricing liquidity risk, i.e. the effect of liquidity on pricing when liquidity is likely to be most needed.

\section{Data and variable construction}

\subsection{Data}

We use intraday European bond quotes and transactions from the MTS interdealer markets for our study. The MTS data include over 750 individual fixed income securities, approximately $88 \%$ are issued by Treasuries and local governments, $5 \%$ are quasi-government securities issued by national and international public institutions, and 7\% are structured securities, consisting mainly of asset-backed and covered fixed income obligations. The data we use spans security trading in 10 European Union member countries: Austria, Belgium, Finland, France Germany Greece, Italy, The Netherlands, Portugal and Spain. ${ }^{3}$ The sample period for our study is April 2003 (corresponding to the beginning of the MTS dataset) to December 2004.

\footnotetext{
${ }^{3}$ While we also have information on Irish securities, the data are too sparse for inclusion in our analysis.
} 
The trading of MTS securities occurs on two separate platforms, domestic and benchmark. The domestic platform lists government securities for each of the respective European countries in the dataset. The benchmark platform trades European benchmark bonds, i.e. newly issued bonds with a minimum issue size. ${ }^{4}$ Note that the benchmark bonds can be traded on both the domestic and benchmark platforms. According to a study of the European bond market by the European Central Bank, the market share of the MTS platforms among the electronic trading systems for bonds in Europe in 2003 was equal to $74 \%$ in terms of daily average turnover. $^{5}$

The MTS dataset contains a host of security identification information such as the issuing country, maturity, coupon, etc., as well as trade and quote information. For the trade information, the dataset contains the date and time of all trades, a buy/sell indicator and the trade price and size. Furthermore, the quote information includes the best bid and offer prices as well as the price and corresponding depth at each of the next two best bid and ask prices on the limit order book. These data allow us to construct yield quotes, liquidity measures and net orderflow (the difference between buyer and seller initiated volume) for each security.

We supplement the MTS data with information about sovereign credit risk from Lombard Risk, an independent valuation service currently owned by Fitch Rating Inc. The data are a compilation of daily surveys of key credit default swap (CDS) market makers for the 3, 5, 7 and 10-year maturities for each country. The data include the date, issuer (in our case, the country), currency of the debt, maturity and the mean and standard deviation (across market makers) of the CDS spread specified in basis points. ${ }^{6}$

We restrict our attention to plain coupon securities in order to minimize the impact of confounding effects related to special fixed income features. Specifically, we exclude securities with floating rate coupons, securities issued in non-euro currencies, securities originating from a coupon-stripping program, inflation- or index-linked securities (OAI and TEC), and securities

\footnotetext{
${ }^{4}$ Note that both the benchmark (EuroMTS) and domestic platforms are wholesale markets where the minimum trading size is 2.5 million euros.

${ }^{5}$ This statistic is based on average daily turnover in 2003 reported by the European Central Bank (2004).

${ }^{6}$ We obtain CDS data for all the countries and maturities in our sample, except for Netherlands at the 3-year and 7year horizon. For more information concerning our credit default swap data, please see http://www.lombardrisk.com/Solutions/Data/ValuspreadCreditHistoricData/index.htm.
} 
traded prior to issue (when issued). Our final dataset consists of plain coupon sovereign securities from the 10 countries for which we have both CDS and MTS information.

\subsection{Variable construction}

We partition our MTS securities along two different dimensions. The first dimension is quite naturally the sovereign yield curve underlying each security. Thus, we separate the MTS securities by country and by benchmark status. The second dimension is the remaining time-tomaturity of a security, which we split into four categories: 2.5-3.5 years, 4.5-5.5 years, 6.5-7.5 years and 9.5-10.5 years. The rationale for these four maturity categories is that both our credit quality data (CDS) and our yield curve benchmark (which will be discussed later) explicitly quote securities at these maturities. We acknowledge that another common dimension used to partition fixed income securities, which we do not use explicitly, is how recently a security was issued or its seasonedness. Our rationale for not separating securities on this dimension is that the status of benchmark security is binding on seasonedness, since benchmark securities must be issued or "tapped” within the previous two years. Thus, our benchmark securities are effectively on-the-run securities by definition. The result is a partition of the MTS securities by domestic versus benchmark status and four maturity categories (3, 5, 7 and 10-years) for each country.

Consistent with the focus of our empirical analysis, we need to construct four crucial sets of variables for each country/maturity: sovereign yield spreads, credit variables, liquidity variables and fund flows which we use to identify flights. We obtain the appropriate sovereign bond yields at the standard reference maturities (3, 5, 7, and 10-years) in two steps. First, for each country and each day in our sample, we fit a zero-coupon yield curve to the coupon bond prices quoted in the last two hours of trading. ${ }^{7}$ We use the Nelson and Siegel (1987) exponential functional form as a convenient approach to model the zero-coupon yield curve. For all countries and days in our sample, we have enough observations to obtain a very accurate fit. In fact, the average absolute yield error for each bond is always below half of a basis point. The second step is to transform each country's zero-coupon yield curve into a par-bond yield curve. This procedure has the intuitive appeal of expressing yields as coupons of bonds selling at par and

\footnotetext{
${ }^{7}$ We exclude from the analysis the bonds with less than two weeks of residual time to maturity, because measurement errors in these cases can induce substantial distortions in yield curve fitting.
} 
fulfills a practical need to express yields on the same basis as our benchmark curve (the fixed leg of an interest rate swap - see below) for comparison purposes.

The calculation of yield spreads necessitates the choice of a benchmark for comparison (sovereign yield spread relative to what). Given the results of Dunne, Moore, and Portes (2003), that the benchmark security within the MTS data varies by maturity and is not always the lowest yield for a given maturity, we refrain from using one of the countries to act as the benchmark. Instead we choose to calculate yield spreads using the Euro-swap curve as our benchmark which is a procedure common to other recent papers in the literature (see for example, McCauley (2002), Hull, Predescu, and White (2004) and Blanco, Brennan, and Marsh (2005)). Collectively they argue that government bonds are less than an ideal proxy for the unobservable risk-free rate, because of differential taxation treatment, repo specials, and scarcity premia. Moreover, the advantages of the Euro-swap benchmark are that it is a bellwether market that is highly liquid, carries relatively little counterparty risk (1 to 2 basis points for 6 months on an AA issuer according to Duffie and Huang (1996)), and provides explicit quotes for the 3, 5, 7 and 10-year maturities. Thus, our yield spread variables are calculated by subtracting the Euro-swap (constant maturity of fixed leg) yield from the sovereign (constant maturity) par-bond yield for each country/maturity category.

We use the Lombard Risk credit default swap data to calculate our credit variables. Recall that the Lombard data provide explicit credit quality quotes for the 3, 5, 7 and 10-year maturities. These data offer an important advantage in that we measure directly the observed term structures of sovereign credit default swap rates for each country, as opposed to estimating credit quality with low frequency national account variables like the ratio of public deficit to GDP. We note that there are occasionally missing observations in the daily time-series of CDS data. However, even in the worst case, at least one observation per week is available and we do not detect distinct patterns of missing data over time or for specific countries. We thus use linear interpolation techniques to obtain a complete set of daily estimates of credit quality for all countries at the different maturities.

The difficulty of working with the notion of liquidity is that there is no universally held definition. To address this issue we consider four different measures to capture the liquidity of the securities in our sample. Our first liquidity measure is the effective bid-ask spread which is 
defined as the spread between the transaction price and the midpoint of the quoted bid-ask spread at the time of the transaction. Average quoted depth, defined as the average of the depth posted at the best bid and best ask prices quoted in millions of euros, is our second liquidity measure. Our third measure is cumulative limit order book depth, where we sum the depth posted at the three best price points on both the buy and sell side of the limit order book and average the two sides together. Our final liquidity measure is a liquidity index as in Bollen and Whaley (1998), which is equal to the average quoted depth divided by the percentage bid-ask spread.

Our measure of fund flows, or flights, for each country/maturity is the daily net orderflow scaled by the net orderflow for the bond market as a whole. Scaling the net orderflow by total net orderflow provides the economically pertinent interpretation that our flight variable is a percentage allocation of funds among the various countries. Net orderflow for a given maturity is calculated using the MTS data by summing the volume of buyside transactions each day for that maturity, summing the volume of sellside transactions each day for that maturity and netting the two by taking their difference (buy volume less sell volume). Net orderflow for the bond market as a whole is computed analogously by summing the net orderflow for each country.

Table 1 contains sample summary statistics related to the number of securities, average trading volume, sovereign yield, credit default swap spread as well as effective bid-ask spread and quoted depth broken out by country and maturity. Notice that there is a fair amount of variation in the credit default spreads and liquidity variables across the countries in our sample. The heterogeneity in these variables will play a central role in our empirical results. In addition, while Germany, France and Italy tend to have the highest number of issues in the dataset, they report vastly different trading volumes, with Italy displaying the largest volume.

As a foray into our empirical analysis we present the raw cross-sectional correlation coefficients between our average credit measure and the various averages of our liquidity measures for each maturity on the benchmark platform. Table 2 shows that the effective spread is negatively related to the default swap spread, that is, as the effective spread decreases, the credit spread increases. The positive coefficients for the depth variables and the liquidity index suggest that as they each increase, the credit spread also increases. Therefore taken together, the results suggest that as liquidity increases, whether via a narrow effective spread or increased depth, credit quality decreases. This table highlights the unique characteristic of the European 
bond market in that credit quality and liquidity are negatively related, making it a perfect environment for disentangling their respective roles. Furthermore, the negative correlation appears weakest for the 3-year maturity and strongest for longer maturities (peaking at the 7-year maturity). Finally, of the four liquidity measures that we use, the liquidity index, which incorporates both spread and depth information, has the strongest correlations with credit quality.

\section{Empirical results}

Having established the negative relation between credit quality and liquidity, we turn our attention to examining which attributes of a security bond investors care most about. We accomplish this by first documenting the relative magnitude of credit quality and liquidity in determining sovereign yield spreads unconditionally. We then test whether the relative importance of these two characteristics changes in periods of heightened market uncertainty. After our investigation of pricing, we shift our attention to trading activity (flights) by directly analyzing the attributes of a security that investors take into account when moving funds into, and out of, the bond market. Finally, we join the two perspectives together by partitioning the yield spread into credit and liquidity components precisely during times of flights. The rationale behind our empirical approach is to be careful to understand how flights affect, and are affected by, changes in credit quality and liquidity.

\subsection{Unconditional yield spread decomposition}

We regress the difference between the sovereign yield in country $i$ and the Euro swap yield onto differences in country $i$ 's credit and liquidity measures from their respective cross-sectional averages, pooling all the countries together for each separate maturity. Equation (1) details our regression model,

$$
\begin{aligned}
& \text { Sovereign Par Yield }{ }_{i, t} \text { - Euro Swap Yield } t_{t}= \\
& \quad \alpha+\beta\left(C D S_{i, t}-C D S_{A V E, t}\right)+\delta\left(L I Q_{i, t}-L I Q_{A V E, t}\right)+\varepsilon_{i, t}
\end{aligned}
$$

where $C D S_{i, t}$ is the credit default swap spread in country $i$ during period $t, L I Q_{i, t}$ is one of the four liquidity measures for country $i$ over period $t$, and $C D S_{A V E, t}$ and $L I Q_{A V E, t}$ are the crosssectional averages of the $C D S_{i, t}$ and $L I Q_{i, t}$ variables respectively during period $t$. 
The exact specification of our model warrants further discussion. While it is not uncommon in the literature to regress yield spreads onto credit and liquidity variables, specifying the credit and liquidity variables as differences from their cross-sectional averages is quite novel. We justify this approach by acknowledging that credit risk and liquidity are relative concepts, particularly in the context of flight-to-quality and flight-to-liquidity. Indeed, an investor considering shifting funds from one asset to another necessarily cares about the relative credit quality and liquidity of the two assets. Thus, we use the cross-sectional average of each of the variables as an anchor point with which to measure the relative credit quality and liquidity of the securities within our sample countries. The time-series behavior of these relative credit quality and liquidity measures (credit and liquidity differentials) for Germany and Italy can be seen in Figure 1, along with a sample of events that are likely to have triggered the sharpest changes. Consistent with our earlier anecdotal evidence, Germany has higher than average credit quality and Italy has lower than average credit quality; in contrast, Italy has higher than average liquidity while Germany has lower than average liquidity. In addition, the figure reveals that the various maturities behave differently, for example, the liquidity differential is more variable both at the end of the sample period and for shorter maturities. Lastly, the credit and liquidity differentials seem to respond to country-specific events. Our empirical results will demonstrate further that harnessing the information embedded in the cross-section of countries in this way offers substantial explanatory power.

We estimate the unconditional regression in Equation (1) for the 3, 5, 7, and 10-year maturities using each of our four liquidity measures. White heteroschedastic consistent standard errors are shown in parentheses, and with one exception all coefficients are significant at the 1\% level. Table 3 reveals that the regression model has significant explanatory power with adjusted $\mathrm{R}^{2}$ ranging from a low of $22 \%$ at the short end of the curve to a high of $57 \%$ for the longer maturities. The success of the regression model reinforces the importance of the cross-section or relative credit and liquidity concepts in explaining sovereign yield spreads.

Consistent with intuition as well as with the previous literature, the credit differential has a positive impact on the sovereign yield spread which suggests that a lower credit quality increases the yield spread. The magnitude of the credit coefficients suggest that a 100 basis point credit differential above the average is associated with an increase in the sovereign yield spread of between 62 and 96 basis points, depending on the maturity and liquidity variable used. 
The liquidity differential is also important in explaining the sovereign yield spread. The positive coefficient on the effective spread and the negative coefficients on the depth variables and liquidity index suggest that higher liquidity is associated with a lower yield spread. In contrast to the credit differential; however, the economic impact of the liquidity differential is muted the longer is the maturity. As an example, a one Euro increase in the effective bid-ask spread is associated with a 231 and 17 basis point increase in the 3-year and 10-year sovereign yield spread respectively. Moreover, the impact of a 100 million Euro increase in quoted depth on the 3 and 10-year sovereign yield spread corresponds to a decrease of 11 and 1 basis point, respectively. Lastly, in comparing the various liquidity measures, while each measure captures the bonds' liquidity, the liquidity index appears to fit the data the best, most likely because it incorporates both price and depth information.

The sign and significance of the constant may appear surprising at first glance, as it suggests that sovereign yields may actually be below the Euroswap yield; however, this is a result of having two different benchmarks (with different credit and liquidity properties) on either side of the regression equation. In particular, the constant accounts for the difference between the credit and liquidity inherent in the Euroswap market and the average credit risk and liquidity in the cross-section.

It is important to highlight that the responses to credit quality and liquidity differ based on maturity. In untabulated results, we estimated the model pooling all countries and maturities together (effectively constraining the coefficients to be identical across maturities). While the signs and significance levels are the same as reported in Table 3 , the adjusted $\mathrm{R}^{2}$ of the constrained specification are substantially smaller (18\%).

Just as the pooled time-series regression results in Table 3 are striking, so too are the model's implications for the cross-section of countries. Table 4 displays the contribution that both the credit and liquidity components provide to the sovereign yield spread for each country. The credit contribution for country $i$ is constructed by taking the average credit differential across time for country $i$ and multiplying it by the relevant credit differential coefficient estimate from Table 3; the liquidity contribution is computed analogously. The proportion figures are calculated by dividing the absolute value of the respective contribution (credit or liquidity) by the sum of the absolute value of the credit and liquidity contributions; thus, the sum of the credit and 
liquidity proportions will be one by construction (see Equation 2). Note that the proportion figures express the impact of credit and liquidity on the variation in yield spreads explained by the regression in Equation (1), rather than the actual yield spread.

$$
\begin{aligned}
\text { Credit Contribution }_{i} & =\hat{\beta} \overline{\left(C D S_{i, t}-C D S_{A V E, t}\right)} \\
\text { Liquidity Contribution }_{i} & =\hat{\delta} \overline{\left(L I Q_{i, t}-L I Q_{A V E, t}\right)} \\
\text { Credit Proportion }_{i} & =\frac{\mid \text { Credit Contribution }_{\mathrm{i}} \mid}{\mid \text { Credit Contribution }_{\mathrm{i}}|+| \text { Liquidity Contribution }_{\mathrm{i}} \mid} \\
\text { Liquidity Proportion }_{i} & =\frac{\mid \text { Liquidity Contribution }_{\mathrm{i}} \mid}{\mid \text { Credit Contribution }_{\mathrm{i}}|+| \text { Liquidity Contribution }_{\mathrm{i}} \mid}
\end{aligned}
$$

The contribution and proportion figures provide complementary information about the relation between credit quality, liquidity and yield spreads. The contribution figures detail the direction and magnitude of credit quality and liquidity, while the proportion figures weigh the relative impact of the two on the sovereign yield spreads. Correspondingly, a country's contribution figures can be positive or negative depending on how that country's credit quality or liquidity compares to the cross-sectional average. By adding a country's contribution figures (along with the constant) we can calculate the average yield spread for that country. Interestingly, there are many countries/maturities with negative sovereign yield spreads owing to the convenience yield of holding government issued securities. ${ }^{8}$

A review of Table 4 shows that unconditionally credit quality makes up the majority of the sovereign yield spread for most countries with liquidity playing a substantially smaller role, a result that is consistent with Longstaff, Mithal, and Neis (2005). Indeed, the grand average of the proportion figures reveals that credit quality makes up $89 \%$ while liquidity is $11 \%$. Beyond the grand average it is important to understand the high degree of heterogeneity in the contribution and proportion figures across countries. A comparison of these figures for Germany and Italy demonstrates the wide range of results. For example, consider the liquidity index regression for the 10-year note, the German contributions for credit and liquidity are -0.0010 and 0.0008 respectively, implying an average yield spread of -0.92 basis points $(-0.90-0.10+0.08){ }^{9}$

\footnotetext{
${ }^{8}$ Supporting evidence for our average sovereign spread estimates can be found on the MTS yield report which is calculated using Euro-government benchmark references as of 11:00 CET daily and located at http://www.mtsgroup.org/newcontent/data/ at "EuroMarket at a Glance".

${ }^{9}$ The contribution figures are multiplied by 100 to facilitate reading; therefore, a contribution of 0.01 is equivalent to 1 basis point.
} 
The corresponding contribution figures for Italy are 0.0487 and -0.0017 for credit and liquidity respectively thereby implying an average yield spread of 3.8 basis points $(-0.90+4.87-0.17)$. The proportion figures for the two countries show similar divergent results. The German proportion figures are 0.57 and 0.43 for credit and liquidity respectively while for Italy they are 0.97 and 0.03. These results are consistent with anecdotal evidence; Germany, known for high credit quality, has a substantial portion of the yield spread due to liquidity while Italy, known for high liquidity, has the overwhelming majority of its yield spread due to credit concerns.

Another interesting aspect bore out in Table 4 is that there are large differences between credit and liquidity proportions for the short and long end of the yield curve. Notice that at the 3 and 5-year maturities there are a number of countries, Belgium, France, Germany and Spain, which have liquidity proportions greater than 0.5 . In contrast, there are no countries, with the exception of two instances for Germany, which have liquidity proportions greater than 0.5 for the 7 and 10-year maturities. Our results suggest that credit quality has both a larger impact and is more important for longer maturities. We believe this result occurs quite naturally given that changes in credit quality are a long-term concern related to changes in fiscal discipline, which in turn is associated with changes in the political/governmental landscape. Given there is likely to be much more uncertainty about the political landscape and fiscal discipline 7 and 10 years into the future, credit quality becomes a more dominant part of the yield spread at longer horizons.

These results are important to our understanding of the primitive forces underlying flights between assets. An important contribution of our paper is documenting a number of crosssectional results related to credit quality and liquidity, as they reveal the force and direction of the 'wind gusts' behind flights. First, yield spreads are explained by the credit quality and liquidity of the assets relative to the credit quality and liquidity of feasible alternatives in the cross-section. Second, there is tremendous heterogeneity across countries and maturities in the magnitude, direction and impact of credit quality and liquidity, which to this point has not been appreciated in the literature. Third, as we will point out in the next section, this relation is timevarying and depends on the level and nature of uncertainty in the marketplace. 


\subsection{Conditional yield spread decomposition}

Beyond our analysis of the unconditional relation between credit quality, liquidity and sovereign yield spreads, we seek to understand how this relation is altered in the face of changes to the market environment. In particular, we investigate various forms of uncertainty, broadly defined, that are guided by both previous academic work and established market trading behavior. In section 4.4 we extend the analysis by specifically conditioning on flights, defined as unusually large capital flows into or out-of the Euro-area bond market.

While many researchers have argued that liquidity is an important consideration when pricing assets, the exact form liquidity takes is still a matter of debate. Pastor and Stambaugh (2003) argue that liquidity risk, namely the possibility that liquidity may be scarce precisely when a market participant wants to exit a position, is the critical aspect of liquidity that is priced. Following the work of Pastor and Stambaugh (2003), we investigate whether liquidity risk is a factor which changes the relative trade-off between credit quality and liquidity for determining yield spreads. Specifically, we condition our analysis on time periods in which market liquidity, as proxied by one of our four liquidity measures, is below its time-series median. From a liquidity risk standpoint, this focuses the analysis on precisely the worst case scenario, i.e., when liquidity in the Euro-area bond market is low and exiting a position is more expensive.

Another uncertainty that we consider is perceived risk in the equity markets. It is not uncommon to hear discussions in the academic or financial press describing a flight out of equities and into fixed income markets when the perceived risk in equity markets rises (e.g., Connolly, Stivers, and Sun, 2005; Underwood, 2006). Given this well-established description of capital flows between these two markets, we consider how the relation between credit quality and liquidity changes when equity markets are perceived to be unusually volatile. We consider two separate measures of perceived equity market volatility, the VIX and VSTOXX indices. The Chicago Board Options Exchange (CBOE) volatility index (VIX) is a measure of U.S. equity market volatility which is constructed using both call and put implied volatilities from S\&P500 index options. The VSTOXX is a similar volatility index for European equity markets that is constructed using implied option prices written on the DJ Euro STOXX 50 index. For each separate volatility index our conditional analysis considers periods where the index is above its respective time-series median. 
Lastly, we also consider the impact of perceived volatility internal to the Euro-area bond market, namely, volatility related to interest rates. Theoretical work by Vayanos (2004) and Acharya and Pedersen (2005) argue that volatility within a market causes that market to value liquidity relatively more. In the face of high market volatility, there may be a higher probability of altering, rebalancing or exiting a position altogether, this in turn puts trading costs at the forefront if market liquidity is time-varying. We proxy for interest rate volatility by conditioning on periods where the implied volatility of a 30-day constant maturity swaption (written on a 10year Euroswap contract) is above its time-series median. ${ }^{10}$

Our conditional analysis entails repeating the base regression analysis conducted above, i.e., equation (1), having first conditioned the sample on periods of low bond market liquidity, high equity market volatility, or high interest rate volatility. Tables 5 and 6 present our conditional results; however, in the interest of parsimony we present results for the liquidity index only, although the results from the other liquidity measures are both qualitatively and quantitatively similar and are available on request. As before, all the coefficients in the conditional regressions (Table 5) are statistically significant at the $1 \%$ level and the signs are consistent with those in the unconditional regressions (Table 3). Recall that the positive coefficient on the credit differential implies that lower credit quality is associated with a higher sovereign yield spread and the negative coefficient on the liquidity differential implies that higher liquidity is associated with a lower sovereign yield spread. Moreover, the adjusted $\mathrm{R}^{2}$ are in general similar across the unconditional and conditional regressions with the conditional regressions producing slightly lower $\mathrm{R}^{2}$ for the 3-year maturity and slightly higher $\mathrm{R}^{2}$ for 5,7 and 10-year maturities. When the model is compared under the various conditioning criteria, conditioning on a high VIX index appears to fit the short end of the curve best while conditioning on high interest rate volatility fits the long end of the curve best. Although, it is clear that no one conditioning set stands out as superior since the $\mathrm{R}^{2}$ across the conditional regressions are roughly the same.

By most statistical measures the unconditional and conditional regressions are very similar; however, the interesting aspect of the comparison is the economic difference in the size

\footnotetext{
${ }^{10}$ As a robustness check we have also conducted the conditional analysis using the lowest quartile for liquidity and the highest quartile for volatility measures. The results are both qualitatively and quantitatively similar to those using the median and are available upon request.
} 
of the respective coefficients. For all conditioning regressions, the size of the coefficient on the credit differential is substantially smaller than the coefficient from the unconditional regression for all maturities but the 10-year. This suggests that the impact of credit quality on the sovereign yield spread is lower when we condition on periods of uncertainty. When we compare the coefficients on the liquidity differential we see that, with one exception, the absolute value of the coefficient is larger, and dramatically so for the 7 and 10-year maturities. Therefore, consistent with a muted impact of credit quality, the impact of liquidity on the sovereign yield spread is substantially increased, particularly on the long-end of the yield curve. Overall, these conditional regressions suggest that the relation between credit quality and liquidity not only varies by country and maturity, it varies through time in response to changes in the level of uncertainty.

Table 6 displays the conditional results broken out by country which leads to a number of interesting insights. It is immediately clear that the liquidity contribution and corresponding proportion figures are much larger for a number of countries. Closer inspection reveals that while there are some differences across conditioning sets, there are noteworthy differences across maturities. In particular, the fraction of countries across the four conditional regressions that register an increase in the liquidity proportion are 1/3, 2/3, 3/4 and 1 for the 3, 5, 7 and 10year maturities respectively. Therefore, consistent with the results in Table 5 , liquidity has a much larger impact on the sovereign yield spread during periods of high uncertainty, especially on the long-end of the curve. Our interpretation of this result is that mobility (the ability to shift funds quickly and cheaply) takes precedence over a trader's valuation concerns during periods of uncertainty. Furthermore, a revealed preference argument suggests that the potential costs associated with investing in an illiquid, creditworthy asset is higher than the costs associated with investing in a liquid, yet less creditworthy, asset during volatile market periods.

\subsection{Flights}

It is clear that the conditional yield spread decomposition points to an increased importance of liquidity during periods of perceived market uncertainty. One explanation of this phenomenon is that when investors defensively rebalance their portfolio toward less risky assets in response to a perceived temporary increase in uncertainty, short-term liquidity and transaction costs concerns become relatively more important and long horizon credit risk becomes relatively less important. 
To explicitly test this explanation, we now directly analyze flights, or large movements of funds, into and out of the Euro area bond market as well as between different countries and maturities. Our direct analysis of flights necessitates an orderflow measure as well as a way of identifying flights from other fund flows. Given that discussions of flight-to-quality and flightto-liquidity are often heard surrounding financial crises such as currency devaluations, the Russian bond default of 1998, and the Long-Term Capital Management debacle, one way that would be quite natural is to look for evidence of funds moving between markets surrounding these events. However, we do not take this tact in our analysis for two reasons. From a practical perspective, these crisis events are very infrequent, and it is difficult to identify specific exogenous events leading up to flights. More importantly from a conceptual perspective, we think about the temporary rebalancing activities hypothesized above as a broader phenomena than simply trading behavior surrounding dramatic events. In addition, our approach allows us to identify flights in a systematic fashion thereby allowing for a better understanding of the catalyst underlying the flights.

Rather than identifying events which may cause flights, we classify flights by identifying periods where there are large positive or large negative total bond market orderflow. Specifically, we classify a flight into the bond market as any day in which the daily net orderflow was in the top quartile of positive net orderflow and analogously we define a flight out of the bond market as any day in which the daily net orderflow was in the bottom quartile of negative net order flow. ${ }^{11}$ Our focus on large absolute orderflow mitigates the confounding effects of trading behavior unassociated with flights, for example, portfolio rebalancing by European central banks, exogenous mutual fund inflows and redemptions, inventory management, etc. Given these behaviors are largely independent, they are likely to offset and have little impact on our flight periods; however, to the extent that they remain, they simply make it more difficult for us to obtain significant results.

After we identify our flight periods we examine the financial news headlines corresponding to those periods using Factiva. In general, the recurring news on days of relevant net bond market order flow describes either optimism or pessimism about economic growth

\footnotetext{
${ }^{11}$ As a robustness check the analysis was also estimated using the median instead of above and below the extreme quartiles. The results display the same signs and significance levels, although the $\mathrm{R}^{2} \mathrm{~s}$, notwithstanding the higher number of observations are lower.
} 
associated with the release of investor confidence numbers. ${ }^{12}$ Other frequent headlines are related to European Central Bank statements about inflation and interest rates. By matching our chosen days with these significant news events we are confident that our classification procedure has identified flights; moreover, the link to these news events provides a context with which the reader can better interpret our results. The core part of our flight analysis entails re-estimating our base regression (Equation 1) for each maturity, replacing the original dependent variable (sovereign yield spreads) by the share of the net bond market orderflow that goes into a specific country. We are able to analyze each maturity class separately because a preliminary investigation shows that flights into or out-of the bond market do not target specific maturity ranges, since the null hypothesis of net bond market orderflow targeting the four maturity classes equally can never be rejected at conventional statistical levels (results not reported).

In addition, we segment the regression based on the direction of the flight as well as the horizon over which we aggregate orderflow. This partition is based on the conjecture that there may be fundamental differences between flights into and out of the bond market related to the asset characteristics being sought and the urgency of the transaction. For example, given the results of the previous sections, we suspect that liquidity will be demanded more aggressively for flights into the bond market, while the trading behavior surrounding flights out of the bond market is unclear. Similarly, we suspect that flights into the bond market are likely to occur very quickly while flights out of the bond market may be transacted over a longer horizon (lower frequency) since there is less urgency to complete the funds transfer. Therefore, our base regression is estimated separately for flights into the bond market and out of the bond market, where flights into (out of) the bond market are identified as the top (bottom) quartile of positive (negative) bond market net order flow, as well as on a daily and weekly basis, where the credit and liquidity differentials and orderflow are aggregated on a 1 day and 5 day horizon respectively.

Lastly, the proportional nature of the dependent variable warrants further examination from an econometric standpoint. The usual non-negativity and unity constraints are not an issue

\footnotetext{
${ }^{12}$ Examples of recurrent headlines on positive bond market net orderflow days are: "Investor optimism fades...”, "No new jobs, no recovery...", "European stock adrift...”.

Examples of headlines on negative net bond market order flow are: "Optimistic expectations contrast with weak current conditions...”, "France Leaving Econ Stagnation...”, "Euro zone business and consumer confidence are finally starting to improve...".
} 
in our setting, since net orderflow can be negative for some countries and, as a result, the proportion can also be greater than one for some other countries. However, in each period, the sum of the proportions for all countries needs to add up to one. Since the two regressors, credit and liquidity differentials, have mean zero by construction, we restrict the intercept to be equal to 0.10 (given 10 countries), so that the add-up constraint is always satisfied.

Table 7 presents the orderflow results, as before, we present the results for the liquidity index only. ${ }^{13}$ It is worth reviewing that orderflow moving into more liquid assets (flight-toliquidity) would show up as positive coefficients on the liquidity differential. Similarly, orderflow moving into assets with high credit quality (flight-to-quality) would manifest itself with negative coefficients on the credit differential.

Beginning with the results for the flights into the bond market at the daily frequency, we see strong evidence of flight-to-liquidity as the coefficients for liquidity are significant at the $1 \%$ level for all maturities. The coefficients on the credit differential are also significant; however, interestingly their signs suggest a 'flee-from' rather than a ‘flight-to' quality. To be clear, we do not believe orderflow is actually moving away from high credit quality assets, rather our methodology has basically set up a 'horse race' between the two characteristics, credit quality and liquidity, and the results clearly show that liquidity dominates. The economic significance of the results is also substantial, as an example, the results for the 10-year maturity suggest that a country with an average credit quality and a liquidity index one standard deviation above the average is associated with an average share of $13 \%$ of total bond market inflow.

The results for flights out of the bond market at the daily frequency are similar in that the coefficients on both the credit and liquidity differential are positive and in general, significant. The sign of the coefficients have the same interpretation as before, since now the dependent variable has both a negative denominator and a negative numerator for the countries that are targets of outflows. Therefore, conditional on a flight out of the bond market the results suggest that investors exiting the bond market are abandoning relatively more liquid and credit risky securities, which reinforces the idea that investors prize the transaction cost component both when they enter and exit the bond market.

\footnotetext{
${ }^{13}$ The results from the other liquidity measures are both qualitatively and quantitatively similar and are available upon request.
} 
When we compare results at the daily and weekly horizons, for flights into the bond market, credit and liquidity differentials explain very little at the weekly horizon, while for flights out of the bond market the results at the daily horizon also obtain at the weekly horizon and with greater explanatory power. ${ }^{14}$ This suggests that bond market inflows occur at a relatively high frequency, being completed within a few days. In contrast, bond market outflows occur at a lower frequency taking a week or more to complete. These results mesh well with intuition as flights into the bond market are likely to be executed with some urgency when exiting a more volatile market, such as the equity markets, and flights out of the bond market are likely to be executed cautiously when entering a riskier market.

Lastly, we also reran the analysis constraining the constant to reflect the null hypothesis of market capitalization proportions for fund flows, rather than the null hypothesis that each country receives an equal proportion (10\%, given 10 countries). This could be for example the outcome of a bond asset allocation strategy with weights based on relative bond market capitalization. The results, (not shown), are both quantitatively and qualitatively similar to those in Table 7.

\section{4. $\quad$ Pricing Conditional on Flights}

The evidence provided thus far shows that, in times of market stress, (1) liquidity becomes relatively more important for bond pricing and (2) the destination of large flow of funds into the bond market is determined almost exclusively by liquidity. In this section, we study whether bond pricing depends more heavily on liquidity precisely during periods of large shifts of funds into or out-of the bond market. This is a natural extension of our analysis given the evidence in the existing literature on the effects of order flow on bond yields (e.g., Brandt and Kavajecz, 2004). Thus, we bring our analysis full circle by explicitly linking a bond's price/yield, credit and liquidity components, and orderflow. We thus examine the relation between sovereign yield spreads, credit quality, and liquidity during days where we observe large net orderflow into and

\footnotetext{
${ }^{14}$ As a robustness check, we have also conducted the same empirical analysis with net orderflow computed at a 2, 3, and 4 day horizon. An increasing horizon determines a monotonic decrease in explanatory power for flows into the bond market and a monotonic increase in the explanatory power for flows out-of the bond market. These results are available upon request.
} 
out-of the bond market. ${ }^{15}$ We also investigate the same relations at the weekly horizon motivated by the timing asymmetry between flights into and out-of the bond market documented in Table 7.

Table 8 presents the results; due to space considerations only the liquidity index and the 10-year maturity are shown. In general, our findings are very similar to the unconditional results of Table 3, except that the coefficients on liquidity are about twice the unconditional magnitude. Specifically, Panel A shows that liquidity becomes relatively more important on days of large bond market inflows or outflows. Panel B shows the results for the weekly horizon. At this lower frequency, liquidity is relatively more important for flights out-of the bond market, consistent with the asymmetric timing results of Table 7. Although not shown, the corresponding contribution and proportion measures show that liquidity explains a higher proportion of the yield spread than the unconditional case for all countries, pointing to an unambiguous increase in the importance of liquidity during flights.

This evidence on pricing during flights links together a number of results that heretofore has been addressed separately. First, we document that fixed income investors are concerned with a specific set of security attributes, in our case credit quality and liquidity. Second, the relative importance of these attributes is dependent on the market environment. Third, flights (orderflow) respond to changes in the relative importance of credit quality and liquidity and fourth, the price of fixed income securities are affected by flights (orderflow). In summary, our results on the linkage of price, attributes and orderflow suggests that the fixed-income market is characterized by traders that care not only about the long-horizon credit risk of a security but also the liquidity of the security, especially during periods of market uncertainty. The heightened demand for liquid securities during these periods manifests itself through both an increased liquidity share of yield spreads and flights into more liquid securities.

\footnotetext{
${ }^{15}$ The conditioning threshold that defines large bond market net orderflow is the top quartile. However, we obtain very similar results by conditioning on other thresholds, such as the bond market orderflow above the median or in the top quintile.
} 


\section{Conclusion}

We determine empirically the extent to which fixed income investors are concerned about credit quality and liquidity unconditionally, as well as conditional on times of heightened market uncertainty. We accomplish this by studying yield spreads and orderflow in the Euro-area government bond market, which exhibits a strong and unique negative relation between credit quality and liquidity, as opposed to the strong positive association found in U.S. debt markets.

Our main empirical finding is that investors demand both credit quality and liquidity, but they do so at different times and for different reasons. We show that the bulk of sovereign yield spreads is explained by differences in credit quality, though liquidity plays a non-trivial role especially for low credit risk countries and during times of heightened market uncertainty. However, the destination of large flows into (as well as out of) the bond market is determined almost exclusively by liquidity. Furthermore, we document that during periods of large flows into or out of the bond market, liquidity explains a substantially greater proportion of sovereign yield spreads, consistent with a heightened impact of order flow on bond prices. This evidence suggests that, while credit quality matters for bond valuation, in times of market stress, investors chase liquidity, not to credit quality.

Our joint focus on pricing and trading activity allows us to document that different attributes of securities have a different importance for investors when they are priced unconditionally versus when they are priced during times of high liquidity demand (flights). Moreover, our findings speak to the larger issue of how a security's risk premium changes with the market trading environment, the security's relative attributes, and flights. 


\section{References}

Acharya, Viral V. and Lasse H. Pedersen, 2005, Asset pricing with liquidity risk, Journal of Financial Economics 77, 375-410.

Amihud, Y. and H. Mendelson, 1986, Asset pricing and the bid-ask spread, Journal of Financial Economics 17, 223-249.

Blanco, Roberto, Simon Brennan and Ian Marsh, 2005, An empirical analysis of the dynamic relation between investment-grade bonds and credit default swaps, Journal of Finance 60, 2255-2281.

Bollen, N. P. and Robert Whaley, 1998, Are teenies better?, Journal of Portfolio Management $25,10-24$.

Brandt, Michael and Kenneth Kavajecz, 2004, Price discovery in the U.S. Treasury market: The impact of orderflow and liquidity on the yield curve, Journal of Finance 59, 2623-2654.

Cheung, Yiu C., Frank de Jong, and Barbara Rindi, 2005, Trading European sovereign bonds: The microstructure of the MTS trading platform, Working paper, University of Amsterdam.

Chordia, T., R. Roll, and A. Subrahmanyam, 2000, Commonality in liquidity, Journal of Financial Economics 56, 3-28.

Codogno, Lorenzo, Carlo Favero and Alessandro Missale, 2003, Yield spreads on EMU government bonds, Economic Policy 503-532.

Collin-Dufresne, Pierre, Robert S. Goldstein, and J. Spencer Martin, 2001, The determinants of credit spread changes, Journal of Finance 56, 2177-2207.

Connolly, Robert A., Christopher T. Stivers, and Licheng Sun, 2005, Stock market uncertainty and the stock-bond return relation, Journal of Financial and Quantitative Analysis 40, 161-194.

Duffie, Darrell and Ming Huang, 1996, Swap rates and credit quality, Journal of Finance 51, 921-949.

Duffie, Darrell, Lasse Pedersen, and Ken Singleton, 2003, Modeling sovereign yield spreads: A case study of Russian debt, Journal of Finance 58, 119-159.

Dunne, Peter G., Michael J. Moore, and Richard Portes, 2003, Defining benchmark status: An application using Euro-area bonds, NBER Working paper 9087.

Ericsson, Jan and Oliver Renault, 2006, Liquidity and credit risk, Journal of Finance, forthcoming.

European Central Bank, 2004, The euro bond market study, Staff Study, Deutsche Bundesbank, ECB, Banque de France and Banca d'Italia.

Favero, Carlo, Marco Pagano and Ernst-Ludwig Von Thadden, 2005, Valuation, liquidity and risk in government bond markets, IGIER Working paper 281. 
Geyer, Alois, Stephan Kossmeier, and Stefan Pichler, 2004, Measuring systematic risk in EMU government yield spreads, Review of Finance 8, 171-197.

Goldreich, David, Bernd Hanke and Purnendu Nath, 2005, The price of future liquidity: Timevarying liquidity in the U.S. Treasury market, Review of Finance 9, 1-32

Hull, John, Mirela Predescu and Alan White, 2004, The relationship between credit default swap spreads, bond yields, and credit rating announcements, Journal of Banking and Finance 28, 2789-2811.

Longstaff, Francis A., 2004, The flight-to-liquidity premium in U.S. Treasury bond prices, Journal of Business 77, 511-526.

Longstaff, Francis A., Sanjay Mithal, and Eric Neis, 2005, Corporate yield spreads: Default risk or liquidity? New evidence from the credit-default swap market, Journal of Finance 55, 2213-2253.

McCauley, Robert, 2002, Panel: Implications of declining treasury debt. International market implications of declining treasury debt, Journal of Money, Credit and Banking 34, 952966.

Menkveld, Albert J., Yiu C. Cheung, and Frank de Jong, 2005, Euro-area sovereign yield dynamics: The role of order imbalance, Working paper, University of Amsterdam.

Nelson, C.R. and A. F. Siegel, 1987, Parsimonious modeling of yield curves, Journal of Business 60, 473-489.

Pastor, Lubos, and Robert F. Stambaugh, 2003, Liquidity risk and expected stock returns, Journal of Political Economy 111, 642-685.

Underwood, Shane, 2006, The cross-market information content of stock and bond order flow, Working paper, Rice University.

Vayanos, Dimitri, 2004, Flight to quality, flight to liquidity, and the pricing of risk, NBER Working paper 10327. 
Table 1

\section{Sample Summary Statistics}

This table presents summary statistics for our sample securities. $\mathrm{N}$ is the number of individual securities in each country/maturity category. Volume represents the average daily trading volume expressed in millions of euros. Par Yld is the average of the par bond yield. CDS is the average credit default swap spread expressed in basis points. Eff Sprd is the average effective bid-ask spread and Depth is the average quoted depth for each country/maturity expressed in millions of euros.

\begin{tabular}{|c|c|c|c|c|c|c|c|c|c|c|c|c|}
\hline \multirow[b]{2}{*}{ Country } & \multicolumn{6}{|c|}{ 3-Year } & \multicolumn{6}{|c|}{ 5-Year } \\
\hline & $\mathrm{N}$ & $\begin{array}{l}\text { Volume } \\
\text { (€ Mil) }\end{array}$ & $\begin{array}{l}\text { Par Yld } \\
\text { (\%) }\end{array}$ & $\begin{array}{l}\text { CDS } \\
\text { (bps) }\end{array}$ & Eff Sprd & $\begin{array}{c}\text { Depth } \\
\text { (€ Mil) }\end{array}$ & $\mathrm{N}$ & $\begin{array}{l}\text { Volume } \\
\text { (€ Mil) }\end{array}$ & $\begin{array}{c}\text { Pr Yld } \\
\text { (\%) }\end{array}$ & $\begin{array}{l}\text { CDS } \\
\text { (bps) }\end{array}$ & Eff Sprd & $\begin{array}{c}\text { Depth } \\
\text { (€ Mil) }\end{array}$ \\
\hline Austria & 4 & 28.01 & 2.83 & 2.69 & 0.0082 & 30.99 & 4 & 25.02 & 3.41 & 3.68 & 0.0104 & 25.04 \\
\hline Belgium & 8 & 37.66 & 2.82 & 3.65 & 0.0072 & 36.03 & 7 & 38.45 & 3.40 & 4.88 & 0.0102 & 31.63 \\
\hline Germany & 41 & 31.54 & 2.86 & 3.55 & 0.0125 & 22.39 & 33 & 28.90 & 3.44 & 5.23 & 0.0150 & 21.48 \\
\hline Spain & 9 & 56.61 & 2.82 & 3.01 & 0.0071 & 35.43 & 10 & 31.50 & 3.41 & 4.61 & 0.0083 & 39.11 \\
\hline Finland & 3 & 65.76 & 2.81 & 2.43 & 0.0068 & 34.00 & 2 & 30.83 & 3.37 & 3.62 & 0.0095 & 27.33 \\
\hline France & 19 & 27.54 & 2.83 & 3.22 & 0.0071 & 31.04 & 21 & 29.34 & 3.40 & 4.69 & 0.0110 & 32.07 \\
\hline Greece & 7 & 39.45 & 2.87 & 8.35 & 0.0072 & 27.91 & 4 & 38.22 & 3.48 & 11.19 & 0.0088 & 23.92 \\
\hline Italy & 28 & 87.09 & 2.83 & 5.93 & 0.0062 & 31.94 & 20 & 98.97 & 3.41 & 8.85 & 0.0067 & 33.73 \\
\hline Netherlands & 6 & 58.79 & 2.82 & & 0.0068 & 30.99 & 6 & 32.23 & 3.39 & 2.76 & 0.0101 & 29.07 \\
\hline Portugal & 7 & 74.29 & 2.84 & 4.87 & 0.0067 & 36.03 & 3 & 32.68 & 3.43 & 7.04 & 0.0084 & 31.68 \\
\hline
\end{tabular}

\begin{tabular}{|c|c|c|c|c|c|c|c|c|c|c|c|c|}
\hline & \multicolumn{6}{|c|}{ 7-Year } & \multicolumn{6}{|c|}{ 10-Year } \\
\hline & $\mathrm{N}$ & $\begin{array}{l}\text { Volume } \\
\text { (€ Mil) }\end{array}$ & $\begin{array}{c}\text { Par Yld } \\
(\%) \\
\end{array}$ & $\begin{array}{l}\text { CDS } \\
\text { (bps) } \\
\end{array}$ & Eff Sprd & $\begin{array}{c}\text { Depth } \\
\text { (€ Mil) }\end{array}$ & $\mathrm{N}$ & $\begin{array}{l}\text { Volume } \\
\text { (€ Mil) }\end{array}$ & $\begin{array}{c}\text { Par Yld } \\
(\%) \\
\end{array}$ & $\begin{array}{l}\text { CDS } \\
\text { (bps) } \\
\end{array}$ & Eff Sprd & $\begin{array}{c}\text { Depth } \\
\text { (€ Mil) }\end{array}$ \\
\hline Austria & 2 & 20.62 & 3.81 & 4.66 & 0.0135 & 19.85 & 2 & 28.60 & 4.17 & 5.93 & 0.0132 & 21.33 \\
\hline Belgium & 3 & 27.88 & 3.80 & 5.81 & 0.0097 & 23.03 & 7 & 44.36 & 4.17 & 6.95 & 0.0119 & 26.01 \\
\hline Germany & 22 & 28.86 & 3.84 & 6.78 & 0.0238 & 19.76 & 12 & 30.73 & 4.20 & 8.32 & 0.0136 & 19.61 \\
\hline Spain & 6 & 23.96 & 3.81 & 6.24 & 0.0140 & 23.48 & 14 & 38.87 & 4.18 & 7.24 & 0.0198 & 22.89 \\
\hline Finland & 1 & 27.77 & 3.78 & 4.25 & 0.0114 & 22.79 & 1 & 33.22 & 4.16 & 4.96 & 0.0160 & 18.86 \\
\hline France & 14 & 23.75 & 3.80 & 5.75 & 0.0360 & 15.26 & 10 & 36.32 & 4.16 & 7.35 & 0.0104 & 26.84 \\
\hline Greece & 3 & 30.42 & 3.90 & 13.55 & 0.0101 & 19.39 & 4 & 53.92 & 4.30 & 16.70 & 0.0114 & 20.11 \\
\hline Italy & 10 & 123.54 & 3.83 & 11.43 & 0.0078 & 23.88 & 5 & 183.90 & 4.22 & 14.11 & 0.0093 & 23.88 \\
\hline Netherlands & 3 & 19.39 & 3.79 & & 0.0118 & 22.40 & 4 & 56.66 & 4.17 & 7.11 & 0.0119 & 22.25 \\
\hline Portugal & 2 & 36.48 & 3.83 & 8.62 & 0.0114 & 23.51 & 2 & 49.36 & 4.21 & 10.35 & 0.0154 & 23.11 \\
\hline
\end{tabular}


Table 2

\section{Correlation between Credit Quality and Liquidity}

This table provides the correlation between the average country credit risk and various measures of average country bond liquidity on the Benchmark platform. A country's credit risk is measured by the average credit default swap (CDS) spread quoted for each country/maturity. Liquidity variables are measured as the country average for bonds with remaining time to maturity centered on the horizon of the CDS plus and minus 6 months.

\begin{tabular}{ccccc} 
& \multicolumn{4}{c}{ Liquidity Variables } \\
\cline { 2 - 4 } Horizon & $\begin{array}{c}\text { Effective } \\
\text { Bid-Ask } \\
\text { Spread }\end{array}$ & $\begin{array}{c}\text { Depth at the best } \\
\text { Bid or Ask }\end{array}$ & $\begin{array}{c}\text { Liquidity Index }= \\
\left(\frac{\text { Quoted Depth }}{\text { Quoted Spread }}\right)\end{array}$ & $\begin{array}{c}\text { Cumulative Limit } \\
\text { Order Book Depth }\end{array}$ \\
\hline \hline 3-year & 0.0358 & 0.1214 & 0.0922 & 0.2626 \\
5-year & -0.1163 & 0.3005 & 0.3839 & 0.4245 \\
7-year & -0.1983 & 0.6375 & 0.7394 & 0.5643 \\
10-year & -0.1573 & 0.2171 & 0.4357 & 0.2692
\end{tabular}


Table 3

\section{Unconditional Relation between Yield Spreads, Credit Quality, and Liquidity}

This table contains the results of the following unconditional regression:

Sovereign Par Yield ${ }_{i, t}-$ EuroSwap Yield $_{t}=\alpha+\beta\left(C D S_{i, t}-C D S_{A V E, t}\right)+\delta\left(L I Q_{i, t}-L I Q_{A V E, t}\right)+\varepsilon_{i, t}$ Sovereign Par Yield $\mathrm{i}_{\mathrm{i}, \mathrm{t}}, \mathrm{CDS}_{\mathrm{i}, \mathrm{t}}$ and $\mathrm{LIQ}_{\mathrm{i}, \mathrm{t}}$ represent the par yield, credit default swap, and liquidity estimates for the given maturity within country i over period t. $\mathrm{CDS}_{\mathrm{AVE}, \mathrm{t}}$ and $\mathrm{LIQ}_{\mathrm{AVE}, \mathrm{t}}$ are the corresponding crosssectional averages at time period $t$. The EuroSwap yield $\mathrm{t}_{\mathrm{t}}$ s the constant maturity fixed leg yield for the given maturity over period t. White heteroschedastic consistent standard errors are shown in parentheses and $* * *$ denotes significance at the $1 \%$ level.

\begin{tabular}{|c|c|c|c|c|}
\hline \multirow[b]{2}{*}{ Variables } & \multicolumn{4}{|c|}{ Liquidity Variables } \\
\hline & $\begin{array}{l}\text { Effective } \\
\text { Bid-Ask } \\
\text { Spread }\end{array}$ & $\begin{array}{l}\text { Depth at the best } \\
\text { Bid or Ask }\end{array}$ & $\begin{array}{c}\text { Liquidity Index = } \\
\left(\frac{\text { Quoted Depth }}{\text { Quoted Spread }}\right)\end{array}$ & $\begin{array}{l}\text { Cumulative Limit } \\
\text { Order Book } \\
\text { Depth }\end{array}$ \\
\hline \multicolumn{5}{|c|}{ 3-Year } \\
\hline Constant & $\begin{array}{l}-0.001266^{* * *} \\
(0.000006)\end{array}$ & $\begin{array}{l}-0.001211^{* * *} \\
(0.000004)\end{array}$ & $\begin{array}{l}-0.001216^{* * *} \\
(0.000004)\end{array}$ & $\begin{array}{l}-0.001212 * * * \\
(0.000004)\end{array}$ \\
\hline Credit differential & $\begin{array}{l}0.006774 * * * \\
(0.000242)\end{array}$ & $\begin{array}{l}0.006240 * * * \\
(0.000226)\end{array}$ & $\begin{array}{l}0.006593 * * * \\
(0.000218)\end{array}$ & $\begin{array}{l}0.006642 * * * \\
(0.000226)\end{array}$ \\
\hline Liquidity differential & $\begin{array}{l}0.023112^{* * *} \\
(0.001313)\end{array}$ & $\begin{array}{l}-0.000011^{* * *} \\
(0.000001)\end{array}$ & $\begin{array}{l}-0.020961^{* * *} \\
(0.000770)\end{array}$ & $\begin{array}{l}-0.000003^{* * *} \\
(0.0000000)\end{array}$ \\
\hline Adjusted $\mathrm{R}^{2}$ & 0.2578 & 0.2685 & 0.3235 & 0.2376 \\
\hline \multicolumn{5}{|c|}{ 5-Year } \\
\hline Constant & $\begin{array}{l}-0.000558^{* * * *} \\
(0.000005)\end{array}$ & $\begin{array}{l}-0.000469 * * * \\
(0.000008)\end{array}$ & $\begin{array}{l}-0.000475^{* * * *} \\
(0.000005)\end{array}$ & $\begin{array}{l}-0.000466 * * * \\
(0.000005)\end{array}$ \\
\hline Credit differential & $\begin{array}{l}0.007278^{* * *} \\
(0.000324)\end{array}$ & $\begin{array}{l}0.007263^{* * *} \\
(0.000212)\end{array}$ & $\begin{array}{l}0.007723^{* * *} \\
(0.000274)\end{array}$ & $\begin{array}{l}0.007365^{* * *} \\
(0.000135)\end{array}$ \\
\hline Liquidity differential & $\begin{array}{l}0.010076^{* * *} \\
(0.001432)\end{array}$ & $\begin{array}{l}-0.000009 * * * \\
(0.000001)\end{array}$ & $\begin{array}{l}-0.021627^{* * *} \\
(0.001541)\end{array}$ & $\begin{array}{l}-0.000003^{* * *} \\
(0.0000000)\end{array}$ \\
\hline Adjusted $\mathrm{R}^{2}$ & 0.2150 & 0.2506 & 0.2738 & 0.2478 \\
\hline \multicolumn{5}{|c|}{ 7-Year } \\
\hline Constant & $\begin{array}{l}-0.000083^{* * *} \\
(0.000013)\end{array}$ & $\begin{array}{l}-0.000072^{* * *} \\
(0.000008)\end{array}$ & $\begin{array}{l}-0.000065^{* * *} \\
(0.000006)\end{array}$ & $\begin{array}{l}-0.000067 * * * \\
(0.000007)\end{array}$ \\
\hline Credit differential & $\begin{array}{l}0.008703^{* * *} \\
(0.000219)\end{array}$ & $\begin{array}{l}0.008702^{* * *} \\
(0.000219)\end{array}$ & $\begin{array}{l}0.009624^{* * *} \\
(0.000207)\end{array}$ & $\begin{array}{l}0.008861^{* * *} \\
(0.000135)\end{array}$ \\
\hline Liquidity differential & $\begin{array}{l}0.002844 * * * \\
(0.000885)\end{array}$ & $\begin{array}{l}-0.000006^{* * *} \\
(0.000002)\end{array}$ & $\begin{array}{l}-0.029363^{* * *} \\
(0.003019)\end{array}$ & $\begin{array}{l}-0.000002 * * * \\
(0.0000001)\end{array}$ \\
\hline Adjusted $\mathrm{R}^{2}$ & 0.3810 & 0.3985 & 0.4256 & 0.4028 \\
\hline \multicolumn{5}{|c|}{ 10-Year } \\
\hline Constant & $\begin{array}{l}-0.000090^{* * *} \\
(0.000005)\end{array}$ & $\begin{array}{l}-0.000090^{* * *} \\
(0.000005)\end{array}$ & $\begin{array}{l}-0.000090^{* * *} \\
(0.000005)\end{array}$ & $\begin{array}{l}-0.000090^{* * *} \\
(0.000005)\end{array}$ \\
\hline Credit differential & $\begin{array}{l}0.008424^{* * *} \\
(0.000138)\end{array}$ & $\begin{array}{l}0.008494^{* * *} \\
(0.000137)\end{array}$ & $\begin{array}{l}0.008598^{* * *} \\
(0.000138)\end{array}$ & $\begin{array}{l}0.008564^{* * *} \\
(0.000135)\end{array}$ \\
\hline Liquidity differential & $\begin{array}{l}0.001720 * * * \\
(0.000486)\end{array}$ & $\begin{array}{l}-0.000001 \\
(0.000001)\end{array}$ & $\begin{array}{l}-0.006293 * * * \\
(0.001985)\end{array}$ & $\begin{array}{l}-0.000001 * * * \\
(0.0000001)\end{array}$ \\
\hline Adjusted $\mathrm{R}^{2}$ & 0.5682 & 0.5673 & 0.5686 & 0.5715 \\
\hline
\end{tabular}


Table 4

Explanatory Power of Credit Quality and Liquidity by Country

This table shows the explanatory power of the credit and liquidity differential on the magnitude of the yield spread on a country by country basis. After estimating the following regression: Sovereign Par Yield ${ }_{i, t}-$ EuroSwap Yield $_{t}=\alpha+\beta\left(C D S_{i, t}-C D S_{A V E, t}\right)+\delta\left(L I Q_{i, t}-L I Q_{A V E, t}\right)+\varepsilon_{i, t}$, we compute for each country (i) the contribution to, and proportion of, the yield spread owing to credit and liquidity as below. The contribution figures are multiplied by 100 to facilitate reading; therefore, a contribution of 0.01 is equivalent to 1 basis point.

$$
\text { Credit Contribution }_{i}=\hat{\beta} \overline{\left(C D S_{i, t}-C D S_{A V E, t}\right)} \text { and Liquidity Contribution }{ }_{i}=\hat{\delta} \overline{\left(L I Q_{i, t}-L I Q_{A V E, t}\right)}
$$

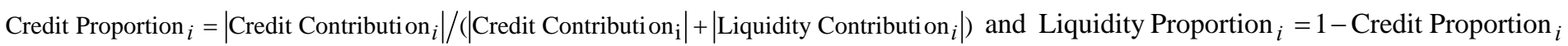

\begin{tabular}{|c|c|c|c|c|c|c|c|c|c|c|c|c|c|c|c|c|}
\hline \multirow[b]{3}{*}{ Country } & \multicolumn{4}{|c|}{ Effective Spread } & \multicolumn{4}{|c|}{ Quoted Depth } & \multicolumn{4}{|c|}{ Liquidity Index } & \multicolumn{4}{|c|}{ Cum. LOB Depth } \\
\hline & \multicolumn{2}{|c|}{ Contribution } & \multicolumn{2}{|c|}{ Proportion } & \multicolumn{2}{|c|}{ Contribution } & \multicolumn{2}{|c|}{ Proportion } & \multicolumn{2}{|c|}{ Contribution } & \multicolumn{2}{|c|}{ Proportion } & \multicolumn{2}{|c|}{ Contribution } & \multicolumn{2}{|c|}{ Proportion } \\
\hline & Credit & Liquid & $\mathrm{Cdt}$ & Liq & Credit & Liquid & $\mathrm{Cdt}$ & Liq & Credit & Liquid & $\mathrm{Cdt}$ & Liq & Cdt & Liquid & Cdt & Liq \\
\hline \multicolumn{17}{|c|}{ 3-Year } \\
\hline Austria & -0.0082 & 0.0027 & 0.75 & 0.25 & -0.0078 & -0.0004 & 0.95 & 0.05 & -0.0082 & 0.0013 & 0.86 & 0.14 & -0.0083 & -0.0035 & 0.70 & 0.30 \\
\hline Belgium & -0.0054 & 0.0026 & 0.68 & 0.32 & -0.0045 & -0.0053 & 0.46 & 0.54 & -0.0048 & -0.0078 & 0.38 & 0.62 & -0.0048 & -0.0044 & 0.52 & 0.48 \\
\hline Germany & -0.0031 & 0.0162 & 0.16 & 0.84 & -0.0028 & 0.0082 & 0.26 & 0.74 & -0.0030 & 0.0145 & 0.17 & 0.83 & -0.0030 & 0.0078 & 0.28 & 0.72 \\
\hline Spain & -0.0071 & 0.0022 & 0.76 & 0.24 & -0.0064 & -0.0061 & 0.51 & 0.49 & -0.0067 & -0.0065 & 0.51 & 0.49 & -0.0068 & -0.0071 & 0.49 & 0.51 \\
\hline Finland & -0.0133 & 0.0022 & 0.86 & 0.14 & -0.0120 & -0.0044 & 0.73 & 0.27 & -0.0127 & -0.0054 & 0.70 & 0.30 & -0.0128 & -0.0013 & 0.91 & 0.09 \\
\hline France & -0.0052 & 0.0030 & 0.63 & 0.37 & -0.0047 & -0.0013 & 0.79 & 0.21 & -0.0050 & 0.0022 & 0.69 & 0.31 & -0.0050 & 0.0011 & 0.82 & 0.18 \\
\hline Greece & 0.0296 & 0.0029 & 0.91 & 0.09 & 0.0262 & 0.0028 & 0.90 & 0.10 & 0.0277 & 0.0038 & 0.88 & 0.12 & 0.0279 & -0.0012 & 0.96 & 0.04 \\
\hline Italy & 0.0130 & 0.0008 & 0.94 & 0.06 & 0.0121 & -0.0022 & 0.85 & 0.15 & 0.0128 & -0.0070 & 0.65 & 0.35 & 0.0129 & -0.0044 & 0.75 & 0.25 \\
\hline Portugal & 0.0058 & 0.0021 & 0.73 & 0.27 & 0.0056 & -0.0053 & 0.51 & 0.49 & 0.0059 & -0.0061 & 0.49 & 0.51 & 0.0060 & -0.0003 & 0.95 & 0.05 \\
\hline \multicolumn{17}{|c|}{ 5-Year } \\
\hline Austria & -0.0133 & 0.0036 & 0.79 & 0.21 & -0.0136 & -0.0009 & 0.94 & 0.06 & -0.0144 & -0.0001 & 1.00 & 0.00 & -0.0138 & -0.0045 & 0.75 & 0.25 \\
\hline Belgium & -0.0064 & 0.0038 & 0.63 & 0.37 & -0.0066 & -0.0093 & 0.42 & 0.58 & -0.0071 & -0.0090 & 0.44 & 0.56 & -0.0067 & -0.0111 & 0.38 & 0.62 \\
\hline Germany & -0.0011 & 0.0131 & 0.08 & 0.92 & -0.0013 & 0.0018 & 0.43 & 0.57 & -0.0014 & 0.0064 & 0.18 & 0.82 & -0.0014 & 0.0022 & 0.39 & 0.61 \\
\hline Spain & -0.0053 & 0.0028 & 0.66 & 0.34 & -0.0055 & -0.0127 & 0.30 & 0.70 & -0.0059 & -0.0140 & 0.30 & 0.70 & -0.0056 & -0.0138 & 0.29 & 0.71 \\
\hline Finland & -0.0135 & 0.0042 & 0.76 & 0.24 & -0.0132 & -0.0035 & 0.79 & 0.21 & -0.0141 & -0.0030 & 0.83 & 0.17 & -0.0134 & -0.0027 & 0.83 & 0.16 \\
\hline France & -0.0045 & 0.0046 & 0.50 & 0.50 & -0.0052 & -0.0087 & 0.37 & 0.63 & -0.0055 & -0.0083 & 0.40 & 0.60 & -0.0052 & -0.0071 & 0.42 & 0.58 \\
\hline Greece & 0.0427 & 0.0035 & 0.92 & 0.08 & 0.0422 & -0.0012 & 0.97 & 0.03 & 0.0448 & -0.0014 & 0.97 & 0.03 & 0.0427 & -0.0028 & 0.94 & 0.06 \\
\hline Italy & 0.0246 & 0.0012 & 0.95 & 0.05 & 0.0244 & -0.0092 & 0.73 & 0.27 & 0.0259 & -0.0154 & 0.63 & 0.37 & 0.0247 & -0.0103 & 0.71 & 0.29 \\
\hline Netherlands & -0.0145 & 0.0052 & 0.74 & 0.26 & -0.0134 & -0.0072 & 0.65 & 0.35 & -0.0142 & -0.0037 & 0.79 & 0.21 & -0.0136 & -0.0065 & 0.68 & 0.32 \\
\hline Portugal & 0.0109 & 0.0037 & 0.75 & 0.25 & 0.0113 & -0.0051 & 0.69 & 0.31 & 0.0121 & -0.0031 & 0.80 & 0.20 & 0.0115 & -0.0054 & 0.68 & 0.32 \\
\hline
\end{tabular}




\section{Table 4, Continued \\ Explanatory Power of Credit Quality and Liquidity by Country}

This table shows the explanatory power of the credit and liquidity differential on the magnitude of the yield spread on a country by country basis. After estimating the following regression: Sovereign Par Yield ${ }_{i, t}-$ EuroSwap Yield $_{t}=\alpha+\beta\left(C D S_{i, t}-C D S_{A V E, t}\right)+\delta\left(L I Q_{i, t}-L I Q_{A V E, t}\right)+\varepsilon_{i, t}$, we compute for each country (i) the contribution to, and proportion of, the yield spread owing to credit and liquidity as below. The contribution figures are multiplied by 100 to facilitate reading; therefore, a contribution of 0.01 is equivalent to 1 basis point.

$$
\text { Credit Contribution }_{i}=\hat{\beta} \overline{\left(C D S_{i, t}-C D S_{A V E, t}\right)} \text { and Liquidity Contribution }{ }_{i}=\hat{\delta} \overline{\left(L I Q_{i, t}-L I Q_{A V E, t}\right)}
$$

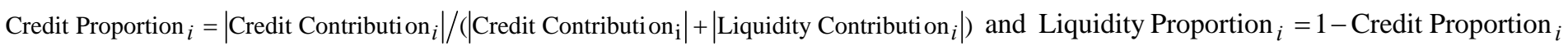

\begin{tabular}{|c|c|c|c|c|c|c|c|c|c|c|c|c|c|c|c|c|}
\hline \multirow[b]{3}{*}{ Country } & \multicolumn{4}{|c|}{ Effective Spread } & \multicolumn{4}{|c|}{ Quoted Depth } & \multicolumn{4}{|c|}{ Liquidity Index } & \multicolumn{4}{|c|}{ Cum. LOB Depth } \\
\hline & \multicolumn{2}{|c|}{ Contribution } & \multicolumn{2}{|c|}{ Proportion } & \multicolumn{2}{|c|}{ Contribution } & \multicolumn{2}{|c|}{ Proportion } & \multicolumn{2}{|c|}{ Contribution } & \multicolumn{2}{|c|}{ Proportion } & \multicolumn{2}{|c|}{ Contribution } & \multicolumn{2}{|c|}{ Proportion } \\
\hline & Credit & Liquid & Cdt & Liq & Credit & Liquid & $\mathrm{Cdt}$ & Liq & Credit & Liquid & $\mathrm{Cdt}$ & Liq & Cdt & Liquid & $\mathrm{Cdt}$ & Liq \\
\hline \multicolumn{17}{|c|}{ 7-Year } \\
\hline Austria & -0.0257 & 0.0017 & 0.94 & 0.06 & -0.0251 & -0.0037 & 0.87 & 0.13 & -0.0278 & -0.0061 & 0.82 & 0.18 & -0.0256 & -0.0034 & 0.88 & 0.12 \\
\hline Belgium & -0.0090 & 0.0004 & 0.96 & 0.04 & -0.0086 & -0.0014 & 0.86 & 0.14 & -0.0095 & -0.0041 & 0.70 & 0.30 & -0.0087 & 0.0007 & 0.92 & 0.08 \\
\hline Germany & -0.0043 & 0.0049 & 0.47 & 0.53 & -0.0048 & -0.0028 & 0.63 & 0.37 & -0.0053 & 0.0042 & 0.56 & 0.44 & -0.0049 & -0.0032 & 0.60 & 0.40 \\
\hline Spain & -0.0148 & 0.0020 & 0.88 & 0.12 & -0.0143 & -0.0039 & 0.79 & 0.21 & -0.0158 & -0.0019 & 0.89 & 0.11 & -0.0146 & -0.0063 & 0.70 & 0.30 \\
\hline Finland & -0.0254 & 0.0014 & 0.95 & 0.05 & -0.0258 & -0.0037 & 0.88 & 0.12 & -0.0285 & -0.0069 & 0.81 & 0.19 & -0.0262 & -0.0051 & 0.84 & 0.16 \\
\hline France & -0.0116 & 0.0074 & 0.61 & 0.39 & -0.0122 & 0.0001 & 0.99 & 0.01 & -0.0135 & 0.0055 & 0.71 & 0.29 & -0.0125 & 0.0026 & 0.83 & 0.17 \\
\hline Greece & 0.0543 & 0.0011 & 0.98 & 0.02 & 0.0541 & -0.0025 & 0.96 & 0.04 & 0.0598 & -0.0066 & 0.90 & 0.10 & 0.0551 & -0.0026 & 0.95 & 0.05 \\
\hline Italy & 0.0375 & 0.0004 & 0.99 & 0.01 & 0.0369 & -0.0050 & 0.88 & 0.12 & 0.0408 & -0.0161 & 0.72 & 0.28 & 0.0375 & -0.0086 & 0.81 & 0.19 \\
\hline Portugal & 0.0118 & 0.0010 & 0.92 & 0.08 & 0.0107 & -0.0028 & 0.79 & 0.21 & 0.0119 & -0.0046 & 0.72 & 0.28 & 0.0109 & -0.0036 & 0.75 & 0.25 \\
\hline \multicolumn{17}{|c|}{ 10-Year } \\
\hline Austria & -0.0212 & -0.0007 & 0.97 & 0.03 & -0.0214 & 0.0002 & 0.99 & 0.01 & -0.0216 & 0.0006 & 0.97 & 0.03 & -0.0215 & 0.0014 & 0.94 & 0.06 \\
\hline Belgium & -0.0147 & -0.0004 & 0.97 & 0.03 & -0.0149 & -0.0004 & 0.98 & 0.02 & -0.0151 & -0.0013 & 0.92 & 0.08 & -0.0150 & -0.0023 & 0.86 & 0.14 \\
\hline Germany & -0.0010 & 0.0015 & 0.41 & 0.59 & -0.0010 & 0.0001 & 0.90 & 0.10 & -0.0010 & 0.0008 & 0.57 & 0.43 & -0.0010 & 0.0006 & 0.63 & 0.37 \\
\hline Spain & -0.0112 & 0.0015 & 0.88 & 0.12 & -0.0113 & -0.0002 & 0.99 & 0.01 & -0.0114 & 0.0006 & 0.95 & 0.05 & -0.0114 & -0.0012 & 0.90 & 0.10 \\
\hline Finland & -0.0314 & -0.0009 & 0.97 & 0.03 & -0.0316 & 0.0010 & 0.97 & 0.03 & -0.0320 & 0.0026 & 0.93 & 0.07 & -0.0319 & 0.0048 & 0.87 & 0.13 \\
\hline France & -0.0120 & -0.0002 & 0.98 & 0.02 & -0.0121 & -0.0005 & 0.96 & 0.04 & -0.0122 & -0.0014 & 0.90 & 0.10 & -0.0122 & -0.0027 & 0.82 & 0.18 \\
\hline Greece & 0.0695 & 0.0004 & 0.99 & 0.01 & 0.0701 & 0.0001 & 1.00 & 0.00 & 0.0710 & -0.0003 & 1.00 & 0.00 & 0.0707 & 0.0010 & 0.99 & 0.01 \\
\hline Italy & 0.0477 & -0.0001 & 1.00 & 0.00 & 0.0481 & -0.0002 & 1.00 & 0.00 & 0.0487 & -0.0017 & 0.97 & 0.03 & 0.0485 & -0.0019 & 0.96 & 0.04 \\
\hline Netherlands & -0.0418 & -0.0005 & 0.99 & 0.01 & -0.0422 & -0.0000 & 1.00 & 0.00 & -0.0427 & 0.0002 & 1.00 & 0.00 & -0.0425 & 0.0004 & 0.99 & 0.01 \\
\hline Portugal & 0.0161 & -0.0005 & 0.97 & 0.03 & 0.0162 & -0.0001 & 1.00 & 0.00 & 0.0164 & 0.0001 & 1.00 & 0.00 & 0.0163 & -0.0000 & 1.00 & 0.00 \\
\hline
\end{tabular}


Table 5

\section{Conditional Relation between Yield Spreads, Credit Quality, and Liquidity}

This table contains the results of the following conditional regression:

Sovereign Par Yield ${ }_{i, t}-$ EuroSwap Yield $_{t}=\alpha+\beta\left(C D S_{i, t}-C D S_{A V E, t}\right)+\delta\left(L I Q_{i, t}-L I Q_{A V E, t}\right)+\varepsilon_{i, t}$ Sovereign Par Yield $\mathrm{i}_{\mathrm{i}, \mathrm{t}}, \mathrm{CDS}_{\mathrm{i}, \mathrm{t}}$ and $\mathrm{LIQ}_{\mathrm{i}, \mathrm{t}}$ represent the par yield, credit default swap, and liquidity estimates for the given maturity within country i over period t. $\mathrm{CDS}_{\mathrm{AVE}, \mathrm{t}}$ and $\mathrm{LIQ}_{\mathrm{AVE}, \mathrm{t}}$ are the corresponding crosssectional averages at time period $t$. The EuroSwap yield $\mathrm{t}_{\mathrm{t}}$ is the constant maturity fixed leg yield for the given maturity over period t. White heteroschedastic consistent standard errors are shown in parentheses and $* * *$ denotes significance at the $1 \%$ level.

Conditioning on

\begin{tabular}{|c|c|c|c|c|}
\hline \multirow[b]{2}{*}{ Variables } & & & & \\
\hline & $\begin{array}{c}\text { Low } \\
\text { Market } \\
\text { Liquidity }\end{array}$ & $\begin{array}{l}\text { High } \\
\text { VIX }\end{array}$ & $\begin{array}{c}\text { High } \\
\text { VSTOXX }\end{array}$ & $\begin{array}{c}\text { High } \\
\text { Interest Rate } \\
\text { Volatility }\end{array}$ \\
\hline \multicolumn{5}{|c|}{ 3-Year } \\
\hline Constant & $\begin{array}{l}-0.001216^{* * *} \\
(0.000006)\end{array}$ & $\begin{array}{l}-0.001223^{* * *} \\
(0.000006)\end{array}$ & $\begin{array}{l}-0.001223^{* * *} \\
(0.000006)\end{array}$ & $\begin{array}{l}-0.001218^{* * *} \\
(0.000006)\end{array}$ \\
\hline Credit differential & $\begin{array}{l}0.005338^{* * * *} \\
(0.000273)\end{array}$ & $\begin{array}{l}0.005125^{* * *} \\
(0.000260)\end{array}$ & $\begin{array}{l}0.005279 * * * \\
(0.000268)\end{array}$ & $\begin{array}{l}0.004834^{* * *} \\
(0.000260)\end{array}$ \\
\hline Liquidity differential & $\begin{array}{l}-0.023831 * * * \\
(0.001726)\end{array}$ & $\begin{array}{l}-0.025103^{* * *} \\
(0.001446)\end{array}$ & $\begin{array}{l}-0.024439 * * * \\
(0.001470)\end{array}$ & $\begin{array}{l}-0.027128 * * * \\
(0.001705)\end{array}$ \\
\hline Adjusted $\mathrm{R}^{2}$ & 0.2851 & 0.3185 & 0.3045 & 0.3094 \\
\hline \multicolumn{5}{|c|}{ 5-Year } \\
\hline Constant & $\begin{array}{l}-0.000559 * * * \\
(0.000015)\end{array}$ & $\begin{array}{l}-0.000518 * * * \\
(0.000010)\end{array}$ & $\begin{array}{l}-0.000526^{* * *} \\
(0.000011)\end{array}$ & $\begin{array}{l}-0.000519 \\
(0.000012)\end{array}$ \\
\hline Credit differential & $\begin{array}{l}0.006073^{* * *} \\
(0.000345)\end{array}$ & $\begin{array}{l}0.005731^{* * *} \\
(0.000297)\end{array}$ & $\begin{array}{l}0.005791^{* * *} \\
(0.000310)\end{array}$ & $\begin{array}{l}0.005714^{* * *} \\
(0.000287)\end{array}$ \\
\hline Liquidity differential & $\begin{array}{l}-0.018439 * * * \\
(0.002858)\end{array}$ & $\begin{array}{l}-0.029918^{* * *} \\
(0.002296)\end{array}$ & $\begin{array}{l}-0.026977 * * * \\
(0.002613)\end{array}$ & $\begin{array}{l}-0.025310 * * * \\
(0.002345)\end{array}$ \\
\hline Adjusted $\mathrm{R}^{2}$ & 0.2549 & 0.3185 & 0.2768 & 0.3020 \\
\hline \multicolumn{5}{|c|}{ 7-Year } \\
\hline Constant & $\begin{array}{l}-0.000034 * * * \\
(0.000006)\end{array}$ & $\begin{array}{l}-0.000044^{* * *} \\
(0.000010)\end{array}$ & $\begin{array}{l}-0.000046^{* * *} \\
(0.000010)\end{array}$ & $\begin{array}{l}-0.000017 \\
(0.000012)\end{array}$ \\
\hline Credit differential & $\begin{array}{l}0.007828 * * * \\
(0.000207)\end{array}$ & $\begin{array}{l}0.008039 * * * \\
(0.000252)\end{array}$ & $\begin{array}{l}0.008027^{* * *} \\
(0.000252)\end{array}$ & $\begin{array}{l}0.007859 * * * \\
(0.000241)\end{array}$ \\
\hline Liquidity differential & $\begin{array}{l}-0.047113^{* * *} \\
(0.005251)\end{array}$ & $\begin{array}{l}-0.051767 * * * \\
(0.005074)\end{array}$ & $\begin{array}{l}-0.049462 * * * \\
(0.004947)\end{array}$ & $\begin{array}{l}-0.047340 * * * \\
(0.004896)\end{array}$ \\
\hline Adjusted $\mathrm{R}^{2}$ & 0.4787 & 0.4592 & 0.4493 & 0.4745 \\
\hline \multicolumn{5}{|c|}{ 10-Year } \\
\hline Constant & $\begin{array}{l}-0.000079 * * * \\
(0.000006)\end{array}$ & $\begin{array}{l}-0.000075^{* * *} \\
(0.000006)\end{array}$ & $\begin{array}{l}-0.000080^{* * *} \\
(0.000006)\end{array}$ & $\begin{array}{l}-0.000042^{* * *} \\
(0.000006)\end{array}$ \\
\hline Credit differential & $\begin{array}{l}0.008776^{* * *} \\
(0.000170)\end{array}$ & $\begin{array}{l}0.008883^{* * *} \\
(0.000174)\end{array}$ & $\begin{array}{l}0.008843^{* * *} \\
(0.000168)\end{array}$ & $\begin{array}{l}0.009121^{* * *} \\
(0.000168)\end{array}$ \\
\hline Liquidity differential & $\begin{array}{l}-0.028827 * * * \\
(0.003226)\end{array}$ & $\begin{array}{l}-0.023233^{* * *} \\
(0.003222)\end{array}$ & $\begin{array}{l}-0.023670^{* * *} \\
(0.003181)\end{array}$ & $\begin{array}{l}-0.033318^{* * *} \\
(0.003239)\end{array}$ \\
\hline Adjusted $\mathrm{R}^{2}$ & 0.5852 & 0.5898 & 0.5957 & 0.6161 \\
\hline
\end{tabular}




\section{Table 6 \\ Conditional Explanatory Power of Credit Quality and Liquidity by Country}

This table shows the explanatory power of the credit and liquidity differential on the magnitude of the yield spread on a country by country basis. After estimating the following regression: Sovereign Par Yield ${ }_{i, t}-$ EuroSwap Yield $_{t}=\alpha+\beta\left(C D S_{i, t}-C D S_{A V E, t}\right)+\delta\left(L I Q_{i, t}-L I Q_{A V E, t}\right)+\varepsilon_{i, t}$, we compute for each country (i) the contribution to, and proportion of, the yield spread owing to credit and liquidity as below. The contribution figures are multiplied by 100 to facilitate reading; therefore, a contribution of 0.01 is equivalent to 1 basis point.

$$
\text { Credit Contribution }_{i}=\hat{\beta} \overline{\left(C D S_{i, t}-C D S_{A V E, t}\right)} \text { and Liquidity Contribution }{ }_{i}=\hat{\delta} \overline{\left(L I Q_{i, t}-L I Q_{A V E, t}\right)}
$$

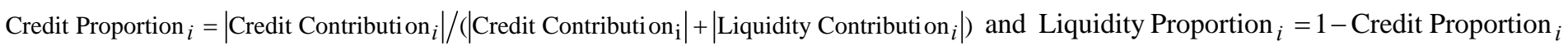

\begin{tabular}{|c|c|c|c|c|c|c|c|c|c|c|c|c|c|c|c|c|}
\hline \multirow[b]{3}{*}{ Country } & \multicolumn{4}{|c|}{ Low Market Liquidity } & \multicolumn{4}{|c|}{ High VIX } & \multicolumn{4}{|c|}{ High VSTOXX } & \multicolumn{4}{|c|}{ High Interest Rate Volatility } \\
\hline & \multicolumn{2}{|c|}{ Contribution } & \multicolumn{2}{|c|}{ Proportion } & \multicolumn{2}{|c|}{ Contribution } & \multicolumn{2}{|c|}{ Proportion } & \multicolumn{2}{|c|}{ Contribution } & \multicolumn{2}{|c|}{ Proportion } & \multicolumn{2}{|c|}{ Contribution } & \multicolumn{2}{|c|}{ Proportion } \\
\hline & Credit & Liquid & Cdt & Liq & Credit & Liquid & Cdt & Liq & Credit & Liquid & Cdt & Liq & Cdt & Liquid & Cdt & Liq \\
\hline \multicolumn{17}{|c|}{ 3-Year } \\
\hline Austria & -0.0060 & -0.0011 & 0.85 & 0.15 & -0.0065 & 0.0001 & 0.99 & 0.01 & -0.0066 & -0.0001 & 0.98 & 0.02 & -0.0055 & -0.0019 & 0.74 & 0.26 \\
\hline Belgium & -0.0048 & -0.0035 & 0.58 & 0.42 & -0.0044 & -0.0051 & 0.46 & 0.54 & -0.0044 & -0.0049 & 0.47 & 0.53 & -0.0044 & -0.0035 & 0.55 & 0.45 \\
\hline Germany & -0.0029 & 0.0124 & 0.19 & 0.81 & -0.0030 & 0.0149 & 0.17 & 0.83 & -0.0030 & 0.0147 & 0.17 & 0.83 & -0.0030 & 0.0151 & 0.17 & 0.83 \\
\hline Spain & -0.0064 & -0.0181 & 0.26 & 0.74 & -0.0062 & -0.0165 & 0.27 & 0.73 & -0.0064 & -0.0157 & 0.29 & 0.71 & -0.0060 & -0.0197 & 0.23 & 0.77 \\
\hline Finland & -0.0124 & -0.0021 & 0.86 & 0.14 & -0.0116 & -0.0042 & 0.73 & 0.27 & -0.0120 & -0.0043 & 0.74 & 0.26 & -0.0114 & -0.0021 & 0.85 & 0.15 \\
\hline France & -0.0051 & -0.0012 & 0.81 & 0.19 & -0.0054 & 0.0001 & 0.99 & 0.01 & -0.0056 & 0.0002 & 0.96 & 0.04 & -0.0053 & -0.0012 & 0.81 & 0.19 \\
\hline Greece & 0.0267 & 0.0052 & 0.84 & 0.16 & 0.0249 & 0.0068 & 0.79 & 0.21 & 0.0257 & 0.0066 & 0.80 & 0.20 & 0.0245 & 0.0071 & 0.77 & 0.23 \\
\hline Italy & 0.0095 & -0.0056 & 0.63 & 0.37 & 0.0087 & -0.0044 & 0.67 & 0.33 & 0.0086 & -0.0041 & 0.68 & 0.32 & 0.0080 & -0.0050 & 0.62 & 0.38 \\
\hline Portugal & 0.0048 & 0.0072 & 0.40 & 0.60 & 0.0035 & -0.0016 & 0.69 & 0.31 & 0.0038 & -0.0017 & 0.69 & 0.31 & 0.0037 & -0.0020 & 0.64 & 0.36 \\
\hline \multicolumn{17}{|c|}{ 5-Year } \\
\hline Austria & -0.0102 & -0.0023 & 0.81 & 0.19 & -0.0111 & -0.0002 & 0.99 & 0.01 & -0.0112 & -0.0001 & 0.99 & 0.01 & -0.0106 & -0.0004 & 0.96 & 0.04 \\
\hline Belgium & -0.0067 & -0.0087 & 0.43 & 0.57 & -0.0058 & -0.0132 & 0.30 & 0.70 & -0.0058 & -0.0120 & 0.32 & 0.68 & -0.0058 & -0.0115 & 0.34 & 0.66 \\
\hline Germany & 0.0006 & 0.0010 & 0.38 & 0.62 & -0.0001 & 0.0052 & 0.01 & 0.99 & 0.0000 & 0.0047 & 0.01 & 0.99 & -0.0004 & 0.0034 & 0.10 & 0.90 \\
\hline Spain & -0.0025 & -0.0153 & 0.14 & 0.86 & -0.0047 & -0.0218 & 0.18 & 0.82 & -0.0046 & -0.0196 & 0.19 & 0.81 & -0.0041 & -0.0198 & 0.17 & 0.83 \\
\hline Finland & -0.0151 & -0.0014 & 0.91 & 0.09 & -0.0133 & -0.0025 & 0.84 & 0.16 & -0.0135 & -0.0023 & 0.86 & 0.14 & -0.0139 & -0.0009 & 0.94 & 0.06 \\
\hline France & -0.0048 & -0.0127 & 0.27 & 0.73 & -0.0047 & -0.0195 & 0.19 & 0.81 & -0.0048 & -0.0179 & 0.21 & 0.79 & -0.0052 & -0.0187 & 0.22 & 0.78 \\
\hline Greece & 0.0397 & -0.0010 & 0.98 & 0.02 & 0.0360 & -0.0007 & 0.98 & 0.02 & 0.0366 & -0.0006 & 0.98 & 0.02 & 0.0362 & -0.0006 & 0.98 & 0.02 \\
\hline Italy & 0.0171 & -0.0076 & 0.69 & 0.31 & 0.0181 & -0.0144 & 0.56 & 0.44 & 0.0179 & -0.0126 & 0.59 & 0.41 & 0.0172 & -0.0114 & 0.60 & 0.40 \\
\hline Netherlands & -0.0122 & -0.0042 & 0.74 & 0.26 & -0.0118 & -0.0067 & 0.64 & 0.36 & -0.0119 & -0.0066 & 0.64 & 0.36 & -0.0109 & -0.0051 & 0.68 & 0.32 \\
\hline Portugal & 0.0088 & -0.0126 & 0.41 & 0.59 & 0.0100 & 0.0026 & 0.79 & 0.21 & 0.0100 & 0.0025 & 0.80 & 0.20 & 0.0113 & 0.0037 & 0.75 & 0.25 \\
\hline
\end{tabular}




\section{Table 6, Continued \\ Conditional Explanatory Power of Credit Quality and Liquidity by Country}

This table shows the explanatory power of the credit and liquidity differential on the magnitude of the yield spread on a country by country basis. After estimating the following regression: Sovereign Par Yield ${ }_{i, t}-$ EuroSwap Yield $_{t}=\alpha+\beta\left(C D S_{i, t}-C D S_{A V E, t}\right)+\delta\left(L I Q_{i, t}-L I Q_{A V E, t}\right)+\varepsilon_{i, t}$, we compute for each country (i) the contribution to, and proportion of, the yield spread owing to credit and liquidity as below. The contribution figures are multiplied by 100 to facilitate reading; therefore, a contribution of 0.01 is equivalent to 1 basis point.

$$
\text { Credit Contribution }_{i}=\hat{\beta} \overline{\left(C D S_{i, t}-C D S_{A V E, t}\right)} \text { and Liquidity Contribution }{ }_{i}=\hat{\delta} \overline{\left(L I Q_{i, t}-L I Q_{A V E, t}\right)}
$$

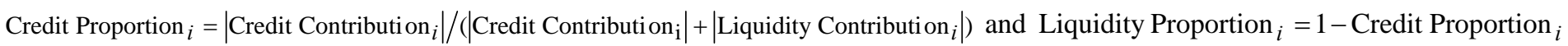

\begin{tabular}{|c|c|c|c|c|c|c|c|c|c|c|c|c|c|c|c|c|}
\hline \multirow[b]{3}{*}{ Country } & \multicolumn{4}{|c|}{ Low Market Liquidity } & \multicolumn{4}{|c|}{ High VIX } & \multicolumn{4}{|c|}{ High VSTOXX } & \multicolumn{4}{|c|}{ High Interest Rate Volatility } \\
\hline & \multicolumn{2}{|c|}{ Contribution } & \multicolumn{2}{|c|}{ Proportion } & \multicolumn{2}{|c|}{ Contribution } & \multicolumn{2}{|c|}{ Proportion } & \multicolumn{2}{|c|}{ Contribution } & \multicolumn{2}{|c|}{ Proportion } & \multicolumn{2}{|c|}{ Contribution } & \multicolumn{2}{|c|}{ Proportion } \\
\hline & Credit & Liquid & $\mathrm{Cdt}$ & Liq & Credit & Liquid & Cdt & Liq & Credit & Liquid & Cdt & Liq & Cdt & Liquid & $\mathrm{Cdt}$ & Liq \\
\hline \multicolumn{17}{|c|}{ 7-Year } \\
\hline Austria & -0.0222 & -0.0118 & 0.65 & 0.35 & -0.0241 & -0.0119 & 0.67 & 0.33 & -0.0242 & -0.0114 & 0.68 & 0.32 & -0.0231 & -0.0116 & 0.67 & 0.33 \\
\hline Belgium & 0.0040 & -0.0025 & 0.61 & 0.39 & -0.0103 & -0.0053 & 0.66 & 0.34 & -0.0105 & -0.0050 & 0.68 & 0.32 & -0.0002 & -0.0116 & 0.02 & 0.98 \\
\hline Germany & -0.0029 & -0.0020 & 0.59 & 0.41 & -0.0028 & 0.0007 & 0.80 & 0.20 & -0.0027 & 0.0005 & 0.84 & 0.16 & -0.0029 & -0.0014 & 0.67 & 0.33 \\
\hline Spain & -0.0094 & -0.0195 & 0.33 & 0.67 & -0.0110 & -0.0125 & 0.47 & 0.53 & -0.0110 & -0.0118 & 0.48 & 0.52 & -0.0095 & -0.0169 & 0.36 & 0.64 \\
\hline Finland & -0.0262 & -0.0099 & 0.72 & 0.28 & -0.0260 & -0.0115 & 0.69 & 0.31 & -0.0263 & -0.0110 & 0.70 & 0.30 & -0.0266 & -0.0096 & 0.74 & 0.26 \\
\hline France & -0.0126 & 0.0019 & 0.87 & 0.13 & -0.0124 & 0.0029 & 0.81 & 0.19 & -0.0125 & 0.0026 & 0.83 & 0.17 & -0.0127 & 0.0020 & 0.87 & 0.13 \\
\hline Greece & 0.0535 & -0.0072 & 0.88 & 0.12 & 0.0538 & -0.0077 & 0.87 & 0.13 & 0.0541 & -0.0074 & 0.88 & 0.12 & 0.0532 & -0.0070 & 0.88 & 0.12 \\
\hline Italy & 0.0289 & -0.0151 & 0.66 & 0.34 & 0.0314 & -0.0192 & 0.62 & 0.38 & 0.0310 & -0.0183 & 0.63 & 0.37 & 0.0296 & -0.0162 & 0.65 & 0.35 \\
\hline Portugal & 0.0080 & -0.0074 & 0.52 & 0.48 & 0.0078 & -0.0027 & 0.74 & 0.26 & 0.0081 & -0.0020 & 0.80 & 0.20 & 0.0086 & -0.0055 & 0.61 & 0.39 \\
\hline \multicolumn{17}{|c|}{ 10-Year } \\
\hline Austria & -0.0221 & 0.0025 & 0.90 & 0.10 & -0.0223 & 0.0021 & 0.92 & 0.08 & -0.0222 & 0.0021 & 0.91 & 0.09 & -0.0229 & 0.0029 & 0.89 & 0.11 \\
\hline Belgium & -0.0154 & -0.0061 & 0.72 & 0.28 & -0.0156 & -0.0049 & 0.76 & 0.24 & -0.0155 & -0.0050 & 0.76 & 0.24 & -0.0160 & -0.0070 & 0.69 & 0.31 \\
\hline Germany & -0.0011 & 0.0036 & 0.22 & 0.78 & -0.0011 & 0.0029 & 0.27 & 0.73 & -0.0011 & 0.0030 & 0.26 & 0.74 & -0.0011 & 0.0042 & 0.21 & 0.79 \\
\hline Spain & -0.0117 & 0.0026 & 0.82 & 0.18 & -0.0118 & 0.0021 & 0.85 & 0.15 & -0.0118 & 0.0022 & 0.84 & 0.16 & -0.0121 & 0.0030 & 0.80 & 0.20 \\
\hline Finland & -0.0327 & 0.0118 & 0.74 & 0.26 & -0.0331 & 0.0095 & 0.78 & 0.22 & -0.0329 & 0.0097 & 0.77 & 0.23 & -0.0340 & 0.0136 & 0.71 & 0.29 \\
\hline France & -0.0125 & -0.0063 & 0.66 & 0.34 & -0.0126 & -0.0051 & 0.71 & 0.29 & -0.0126 & -0.0052 & 0.71 & 0.29 & -0.0130 & -0.0073 & 0.64 & 0.36 \\
\hline Greece & 0.0724 & -0.0014 & 0.98 & 0.02 & 0.0733 & -0.0012 & 0.98 & 0.02 & 0.0730 & -0.0012 & 0.98 & 0.02 & 0.0753 & -0.0017 & 0.98 & 0.02 \\
\hline Italy & 0.0497 & -0.0079 & 0.86 & 0.14 & 0.0503 & -0.0064 & 0.89 & 0.11 & 0.0501 & -0.0065 & 0.89 & 0.12 & 0.0516 & -0.0092 & 0.85 & 0.15 \\
\hline Netherlands & -0.0436 & 0.0009 & 0.98 & 0.02 & -0.0441 & 0.0007 & 0.98 & 0.02 & -0.0439 & 0.0007 & 0.98 & 0.02 & -0.0453 & 0.0010 & 0.98 & 0.02 \\
\hline Portugal & 0.0167 & 0.0003 & 0.98 & 0.02 & 0.0170 & 0.0002 & 0.99 & 0.01 & 0.0169 & 0.0002 & 0.99 & 0.01 & 0.0174 & 0.0003 & 0.98 & 0.02 \\
\hline
\end{tabular}


Table 7

Relation between Net Orderflow, Credit Quality, and Liquidity

This table contains the results of the following conditional regression:

$$
\frac{\text { Net Orderflow }_{i, t}}{\sum_{\mathrm{i}=1}^{10} \text { Net Orderflow }_{i}}=\bar{\alpha}+\beta\left(C D S_{i, t}-C D S_{A V E, t}\right)+\delta\left(L I Q_{i, t}-L I Q_{A V E, t}\right)+\varepsilon_{i, t}
$$

Net Orderflow $\mathrm{w}_{\mathrm{i}, \mathrm{t}}, \mathrm{CDS}_{\mathrm{i}, \mathrm{t}}$ and $\mathrm{LIQ}_{\mathrm{i}, \mathrm{t}}$ represent the daily net orderflow, credit default swaps, and liquidity estimates for the given maturity within country i over period t. $\mathrm{CDS}_{\mathrm{AVE}, \mathrm{t}}$ and $\mathrm{LIQ}_{\mathrm{AVE}, \mathrm{t}}$ are the corresponding cross-sectional averages at time period t. The intercept is restricted to be equal to 0.10 to guarantee the add-up constraint. White heteroschedastic consistent standard errors are shown in parentheses and $* * *$ denotes significance at the $1 \%$ level.

Flights into Bond Market Flights out of the Bond Market

\begin{tabular}{cccc}
\hline $\begin{array}{c}\text { Daily Relative } \\
\text { Order Flow }\end{array}$ & $\begin{array}{c}\text { Weekly Relative } \\
\text { Order Flow }\end{array}$ & $\begin{array}{c}\text { Daily Relative } \\
\text { Order Flow }\end{array}$ & $\begin{array}{c}\text { Weekly Relative } \\
\text { Order Flow }\end{array}$
\end{tabular}

Variables

3-Year

\begin{tabular}{|c|c|c|c|c|}
\hline \\
\hline Constant & 0.100000 & 0.100000 & 0.100000 & 0.100000 \\
\hline Credit differential & $\begin{array}{l}1.052116 * * \\
(0.509315)\end{array}$ & $\begin{array}{l}0.531097 \\
(1.129030)\end{array}$ & $\begin{array}{l}1.364640 * * * \\
(0.435174)\end{array}$ & $\begin{array}{l}1.525500 * \\
(0.956943)\end{array}$ \\
\hline Liquidity differential & $\begin{array}{l}0.000039 * * \\
(0.000017)\end{array}$ & $\begin{array}{l}0.000004 \\
(0.000031)\end{array}$ & $\begin{array}{l}0.000021 \\
(0.000017)\end{array}$ & $\begin{array}{l}0.000053 \\
(0.000037)\end{array}$ \\
\hline Adjusted $\mathrm{R}^{2}$ & 0.0219 & 0.0028 & 0.0193 & 0.0430 \\
\hline \multicolumn{5}{|c|}{ 5-Year } \\
\hline Constant & 0.100000 & 0.100000 & 0.100000 & 0.100000 \\
\hline Credit differential & $\begin{array}{l}1.005941^{* * *} \\
(0.344639)\end{array}$ & $\begin{array}{l}0.705913 \\
(0.696261)\end{array}$ & $\begin{array}{l}1.161905^{* * *} \\
(0.271539)\end{array}$ & $\begin{array}{l}1.240522 * * \\
(0.523814)\end{array}$ \\
\hline Liquidity differential & $\begin{array}{l}0.000111^{* * *} \\
(0.000022)\end{array}$ & $\begin{array}{l}0.000024 \\
(0.000043)\end{array}$ & $\begin{array}{l}0.000123^{* * *} \\
(0.000018)\end{array}$ & $\begin{array}{l}0.000125 * * * \\
(0.000037)\end{array}$ \\
\hline Adjusted $\mathrm{R}^{2}$ & 0.1008 & 0.0190 & 0.1167 & 0.1422 \\
\hline \multicolumn{5}{|c|}{ 7-Year } \\
\hline Constant & 0.100000 & 0.100000 & 0.100000 & 0.100000 \\
\hline Credit differential & $\begin{array}{l}1.521246 * * * \\
(0.264495)\end{array}$ & $\begin{array}{l}1.327866 * * * \\
(0.433643)\end{array}$ & $\begin{array}{l}1.498395^{* * *} \\
(0.273926)\end{array}$ & $\begin{array}{l}1.652711^{* * *} \\
(0.495547)\end{array}$ \\
\hline Liquidity differential & $\begin{array}{l}0.000199 * * * \\
(0.000030)\end{array}$ & $\begin{array}{l}0.000126^{* * *} \\
(0.000042)\end{array}$ & $\begin{array}{l}0.000096 * * \\
(0.000044)\end{array}$ & $\begin{array}{l}0.000114 * \\
(0.000070)\end{array}$ \\
\hline Adjusted $\mathrm{R}^{2}$ & 0.1965 & 0.1211 & 0.0777 & 0.1401 \\
\hline \multicolumn{5}{|c|}{ 10-Year } \\
\hline Constant & 0.100000 & 0.100000 & 0.100000 & 0.100000 \\
\hline Credit differential & $\begin{array}{l}0.729417 * * \\
(0.285290)\end{array}$ & $\begin{array}{l}-0.647845 \\
(0.509452)\end{array}$ & $\begin{array}{l}0.682337 * * * \\
(0.203988)\end{array}$ & $\begin{array}{l}0.884258^{* *} \\
(0.390730)\end{array}$ \\
\hline Liquidity differential & $\begin{array}{l}0.000112 * * * \\
(0.000025)\end{array}$ & $\begin{array}{l}0.000076 \\
(0.000053)\end{array}$ & $\begin{array}{l}0.000150 * * * \\
(0.000031)\end{array}$ & $\begin{array}{l}0.000190 * * * \\
(0.000057)\end{array}$ \\
\hline Adjusted $\mathrm{R}^{2}$ & 0.0493 & 0.0237 & 0.0677 & 0.1443 \\
\hline
\end{tabular}


Table 8

Yield Spreads, Credit Quality, and Liquidity Conditional on Large Net Orderflow

This table contains the results of the following conditional regression:

Sovereign Par Yield ${ }_{i, t}-$ EuroSwap Yield $_{t}=\alpha+\beta\left(C D S_{i, t}-C D S_{A V E, t}\right)+\delta\left(L I Q_{i, t}-L I Q_{A V E, t}\right)+\varepsilon_{i, t}$ Sovereign Par Yield $\mathrm{i}_{\mathrm{i}, \mathrm{t}} \mathrm{CDS}_{\mathrm{i}, \mathrm{t}}$ and $\mathrm{LIQ}_{\mathrm{i}, \mathrm{t}}$ represent the par yield, credit default swap, and liquidity estimates for the given maturity within country i over period t. $\mathrm{CDS}_{\mathrm{AVE}, \mathrm{t}}$ and $\mathrm{LIQ}_{\mathrm{AVE}, \mathrm{t}}$ are the corresponding crosssectional averages at time period $t$. The EuroSwap yield $\mathrm{t}_{\mathrm{t}}$ is the constant maturity fixed leg yield for the given maturity over period t. Panel A and B show the results conditional on large daily and weekly net orderflow, respectively. White heteroschedastic consistent standard errors are shown in parentheses and *** denotes significance at the $1 \%$ level.

\begin{tabular}{|c|c|c|c|}
\hline \multicolumn{4}{|c|}{ Panel A: Daily Order Flow } \\
\hline \multirow{3}{*}{ Variables } & \multicolumn{3}{|c|}{ Conditioning on } \\
\hline & $\begin{array}{c}\text { Large } \\
\text { Absolute } \\
\text { Bond Market } \\
\text { Net Orderflow }\end{array}$ & $\begin{array}{c}\text { Large } \\
\text { Positive } \\
\text { Bond Market } \\
\text { Net Orderflow }\end{array}$ & $\begin{array}{c}\text { Large } \\
\text { Negative } \\
\text { Bond Market } \\
\text { Net Orderflow }\end{array}$ \\
\hline & \multicolumn{3}{|c|}{ 10-Year } \\
\hline Constant & $\begin{array}{l}-0.000048^{* * *} \\
(0.000010)\end{array}$ & $\begin{array}{l}-0.000046^{* * * *} \\
(0.000021)\end{array}$ & $\begin{array}{l}-0.000038 * * * \\
(0.000020)\end{array}$ \\
\hline Credit differential & $\begin{array}{l}0.008828 * * * \\
(0.000285)\end{array}$ & $\begin{array}{l}0.008851^{* * * *} \\
(0.000597)\end{array}$ & $\begin{array}{l}0.009342^{* * *} \\
(0.000566)\end{array}$ \\
\hline Liquidity differential & $\begin{array}{l}-0.011402 * * * \\
(0.004585)\end{array}$ & $\begin{array}{l}-0.010107 * * * \\
(0.004510)\end{array}$ & $\begin{array}{l}-0.011432 * * * \\
(0.005709)\end{array}$ \\
\hline Adjusted $\mathrm{R}^{2}$ & 0.5727 & 0.5784 & 0.5976 \\
\hline
\end{tabular}

Panel B: Weekly Order Flow

\begin{tabular}{llll} 
& \multicolumn{3}{c}{ Conditioning on } \\
\cline { 2 - 4 } Variables & \multicolumn{1}{c}{$\begin{array}{c}\text { Large } \\
\text { Absolute } \\
\text { Bond Market } \\
\text { Net Orderflow }\end{array}$} & $\begin{array}{c}\text { Large } \\
\text { Positive } \\
\text { Bond Market } \\
\text { Net Orderflow }\end{array}$ & $\begin{array}{c}\text { Large } \\
\text { Negative } \\
\text { Bond Market } \\
\text { Net Orderflow }\end{array}$ \\
\hline \hline Constant & \multicolumn{1}{c}{$\mathbf{1 0 - Y e a r}$} \\
Credit differential & $-0.000062^{* * *}$ & $-0.000053^{* * *}$ & $-0.000073^{* * *}$ \\
Liquidity differential & $(0.000004)$ & $(0.000006)$ & $(0.000006)$ \\
& $0.008900^{* * *}$ & $0.008555^{* * *}$ & $0.009203^{* * *}$ \\
Adjusted $\mathrm{R}^{2}$ & $(0.000126)$ & $(0.000188)$ & $(0.000166)$ \\
& $-0.012801^{* * *}$ & $-0.007224^{* * *}$ & $-0.018888^{* * *}$ \\
& $(0.002063)$ & $(0.002811)$ & $(0.003007)$ \\
& 0.5768 & 0.5496 & 0.6077
\end{tabular}


Figure 1

\section{Time-series of Credit and Liquidity Differentials for Germany and Italy}

The credit and liquidity differentials are the difference between the German and Italian CDS and liquidity measures and the cross-sectional average at each point in time. The markers, A- $\mathrm{H}$, represent the following periods and events: (A) July 2003, the European Union asked the Italian government to reduce its "structural deficit" by 0.5 pct of GDP and to cut the public debt. (B) January 2004, the European Union finds Italy's stability program scarcely credible, due to a scenario of over optimistic growth and budgetary measures that were too imprecise. (C) November 2004, European Union Commission is 'Worried' About Italy Deficit Outlook. (D) August 2003, European Union says Germany can still bring its public deficit back within strict European Union guidelines next year. (E) September 2003, the German central bank warns that the German public deficit will break the ceiling laid down in the European Stability Pact for the third year in a row. (F) November 2004, the International Monetary Fund and the German central bank express their skepticism that the German government will be able to reach its deficit target. (G) March 2004, German government first quarter new borrowing exceeds redemptions by a record 20 billions euros, with 16 billions topping up the 10-year maturity. (H) May 2004, the European bond market awaits cheaper new three-year and ten-year Italian bonds to be auctioned at the end of the week.
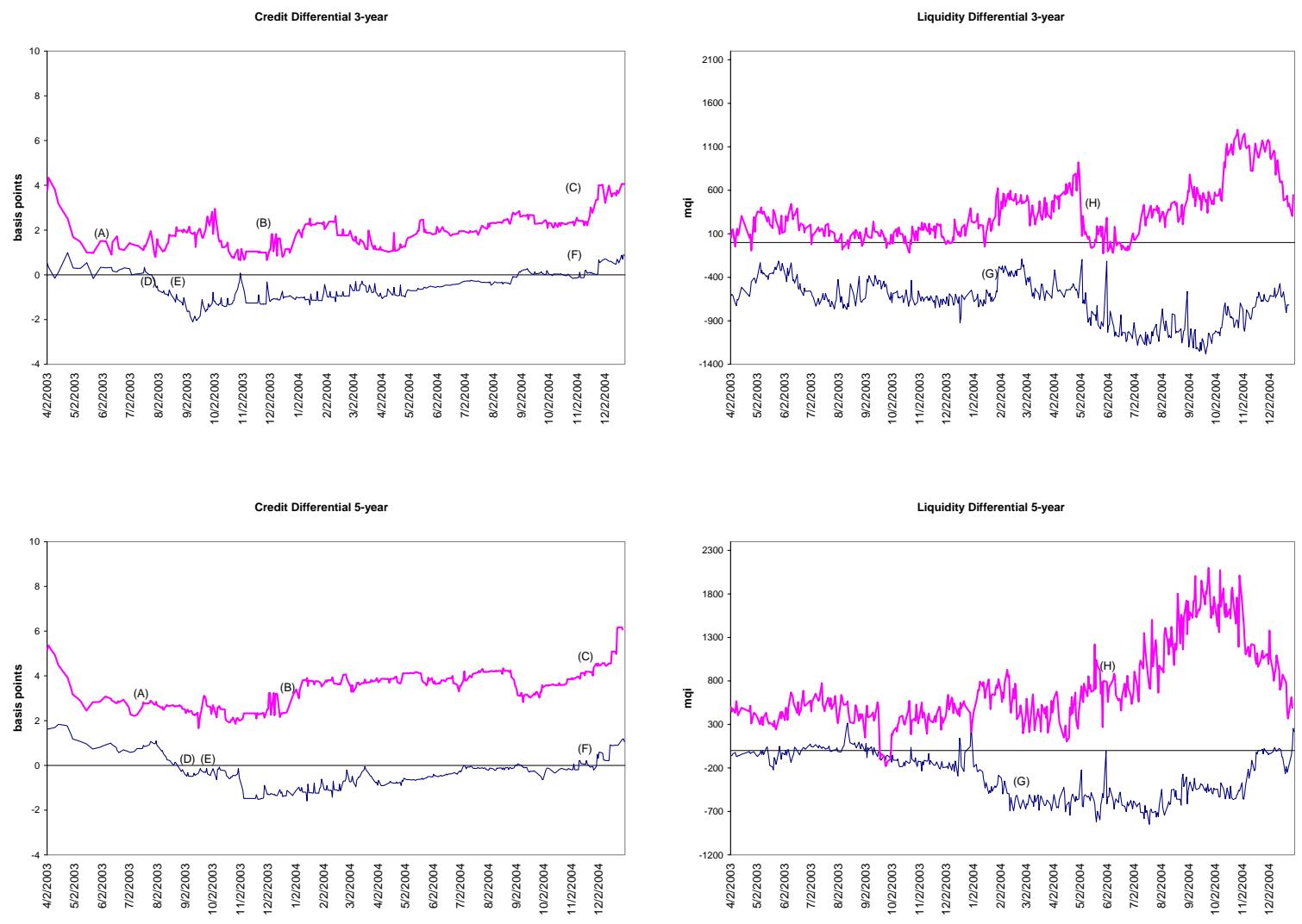


\section{Figure 1, Continued \\ Time-series of Credit and Liquidity Differentials for Germany and Italy}

The credit and liquidity differentials are the difference between the German and Italian CDS and liquidity measures and the cross-sectional average at each point in time. The markers, A- $\mathrm{H}$, represent the following periods and events: (A) July 2003, the European Union asked the Italian government to reduce its "structural deficit" by 0.5 pct of GDP and to cut the public debt. (B) January 2004, the European Union finds Italy's stability program scarcely credible, due to a scenario of over optimistic growth and budgetary measures that were too imprecise. (C) November 2004, European Union Commission is 'Worried' About Italy Deficit Outlook. (D) August 2003, European Union says Germany can still bring its public deficit back within strict European Union guidelines next year. (E) September 2003, the German central bank warns that the German public deficit will break the ceiling laid down in the European Stability Pact for the third year in a row. (F) November 2004, the International Monetary Fund and the German central bank express their skepticism that the German government will be able to reach its deficit target. (G) March 2004, German government first quarter new borrowing exceeds redemptions by a record 20 billions euros, with 16 billions topping up the 10-year maturity. (H) May 2004, the European bond market awaits cheaper new three-year and ten-year Italian bonds to be auctioned at the end of the week.
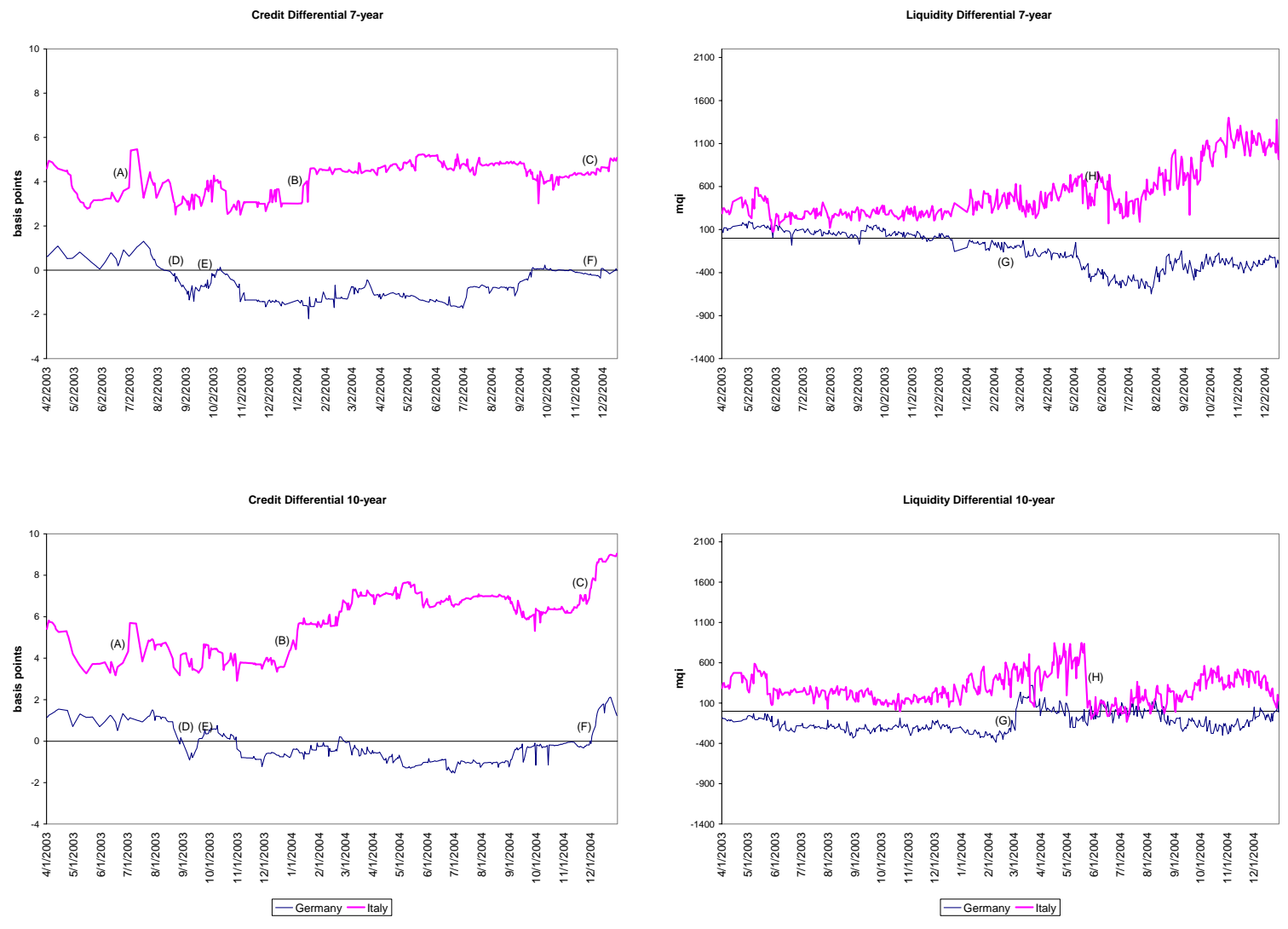